\title{
Real-Time Quantitative and lon-Metal Indicator LAMP-Based Assays for Rapid Detection of Sclerotinia sclerotiorum
}

\author{
Edilaine Mauricia Gelinski Grabicoski, ${ }^{1,2, \dagger}$ David de Souza Jaccoud-Filho, ${ }^{1}$ David Lee, ${ }^{3}$ Luciane Henneberg, ${ }^{1}$ and Marcos Pileggi ${ }^{4}$ \\ ${ }^{1}$ State University of Ponta Grossa, Department of Plant Science and Plant Protection, Uvaranas, 84030-900, Ponta Grossa, PR, \\ Brazil \\ ${ }^{2}$ State University of Maringá, Department of Agronomy, Jardim Universitário, 87020-900, Maringá, PR, Brazil \\ ${ }^{3}$ National Institute of Agricultural Botany, Cambridge CB3 OLE, United Kingdom \\ ${ }^{4}$ State University of Ponta Grossa, Department of Structural, Molecular and Genetic Biology, Uvaranas, 84030-900, Ponta \\ Grossa, PR, Brazil
}

\begin{abstract}
Sclerotinia sclerotiorum is one of the most devastating and cosmopolitan plant pathogens. Rapid detection of $S$. sclerotiorum can provide growers an advantage in knowing what control measures should be taken to minimize crop damage and financial losses caused by it. Loop-mediated isothermal amplification (LAMP) is a fast, sensitive, and specific nucleic acid amplification method that does not require a thermal cycler. This study aimed to develop a LAMP-based assay for the specific detection of $S$. sclerotiorum (Ss-LAMP). A real-time quantitative LAMP reaction (Ss-qLAMP) and a calcein ion indicator-based LAMP reaction (SscLAMP) were designed, optimized, and tested on fungi, plant, and soil samples. The Ss-LAMP reactions were very specific and sensitive. Ap-

infected soybean tissues had the pathogen detected by Ss-cLAMP directly in the reaction tube with no DNA extraction requirement. The assays should be applicable for many types of samples, such as soil, spore traps, and plant tissues from several crops, with no requirement for DNA extraction. The Ss-LAMP reactions took less than $1 \mathrm{~h}$ to complete, and they can be made directly in the field with real-time quantitative results (Ss-qLAMP) or qualitative naked-eye visual results (Ss-cLAMP). Results were obtained with $10 \mathrm{pg}$ of DNA or $10 \mathrm{ng}$ of crude mycelium, suggesting a detection limit close to a single DNA copy. Ss-LAMP reactions will allow rapid and accurate diagnosis of $S$. sclerotiorum and assist in pathogen management and control.
\end{abstract} plying the artificially inoculated soil samples with DNA purified by five protocols in the Ss-qLAMP reaction, it was possible to detect and quantify the pathogen DNA, regardless of the extraction protocol. Naturally
Keywords: white mold, diagnostic, molecular test, calcein, visual detection, field detection
Sclerotinia sclerotiorum (Lib.) de Bary is one of the most devastating and cosmopolitan plant pathogens (Bolton et al. 2006). More than 60 names have been used to refer to diseases caused by this fungal pathogen (Purdy 1979), including cottony rot, watery soft rot, stem rot, drop, crown rot, blossom blight, and perhaps most commonly, white mold. This fungus can infect more than 400 plant species from 278 genera and 75 families, including many important and economically valuable agricultural crops, such as soybean and rapeseed (Boland and Hall 1994), for which it is considered a serious threat to production (del Río et al. 2007; Peltier et al. 2012). S. sclerotiorum is disseminated by airborne ascospores, and such fungal spores, mycelium, and sclerotia can contaminate many types of samples, such as soil, seeds, and plant tissues (Bolton et al. 2006; Neergaard 1979; Purdy 1979).

Rapid detection of $S$. sclerotiorum in samples can facilitate control of the disease and spread of the pathogen. The most common method currently used for the rapid detection of S. sclerotiorum is based on

${ }^{\dagger}$ Corresponding author: E. M. G. Grabicoski; e.grabicoski@gmail.com

Funding: This study was funded by a research grant provided by the Conselho Nacional de Desenvolvimento Científico e Tecnológico (Brazilian National Research Council; Edital 064/2008) and MAPA (Brazilian Ministry of Agriculture). We are grateful to the CAPES Foundation (Coordenação de Aperfeiçoamento de Pessoal de Nível Superior) for a scholarship and the Fundação Araucária for a scholarship.

*The $\boldsymbol{e}$-Xtra logo stands for "electronic extra" and indicates that three supplementary figures are published online.

The author(s) declare no conflict of interest.

Accepted for publication 9 October 2019.

(C) 2020 The American Phytopathological Society the conventional polymerase chain reaction (PCR) technique (AbdElmagid et al. 2013; Freeman et al. 2002; Grabicoski et al. 2015; Jones et al. 2015; Qin et al. 2011). Although PCR is a standard method in biotechnology, it has several intrinsic disadvantages, including the requirement for rapid thermal cycling, insufficient specificity, and relatively low amplification efficiency (Freeman et al. 2002; Notomi et al. 2000).

Loop-mediated isothermal amplification (LAMP) is a nucleic acid amplification method that was first reported in 2000 by Notomi et al. (2000). This method requires a Bacillus stearothermophilus DNA polymerase with strand-displacement activity and a set of four to six specially designed primers based on six or eight distinct regions of the target DNA. LAMP products are visualized with the naked eye by first adding DNA-intercalating dyes, such as ethidium bromide, SYBR Green, and Quant-iT PicoGreen. Then a metal-ion indicator, such as hydroxynaphthol blue (Goto et al. 2009), $\mathrm{CuSO}_{4}$ (Zoheir and Allam 2011), or calcein (Tomita et al. 2008), is added, or, alternatively, the increase in turbidity resulting from magnesium pyrophosphate formation (to infer increases in the amplified DNA concentration) is measured. LAMP products can also be detected with real-time detection methods (Denschlag et al. 2014; Mori et al. 2004). The simplicity of the LAMP method, which does not require a thermal cycler, makes it suitable for field applications. In the field of microbiology, LAMP has been applied to detect and identify bacteria (Iwamoto et al. 2003; Neonakis et al. 2011), viruses (Parida et al. 2004; Thai et al. 2004), and fungi (Denschlag et al. 2014; Duan et al. 2014a, 2014b).

The present study aimed to develop a LAMP assay capable of quantitatively detecting $S$. sclerotiorum and that was also suitable for field testing.

\section{Materials and Methods}

Fungal strains. The following strains and samples were used in the present study: sclerotia of 57 isolates of S. sclerotiorum collected from infested Brazilian soybean fields; pure cultures of Sclerotium 
rolfsii, Trichoderma sp., Aspergillus sp., Penicillium sp., Macrophomina phaseolina, Colletotrichum sp., Rhizopus sp., and Sclerotinia minor; the tegument of soybean seeds infected by Peronospora manshurica; the DNA of other fungi available from the Laboratory of Applied Plant Pathology (LAPP) of Universidade Estadual de Ponta Grossa (UEPG), Ponta Grossa, Paraná, Brazil (Cercospora sojina, Phomopsis sojae, Aspergillus sp., Cercospora kikuchii, Fusarium sp., and Colletotrichum truncatum) and from the National Institute of Agricultural Botany (NIAB), Cambridge, United Kingdom ( $S$. sclerotiorum, Rhizoctonia sp., Stemphylium sp., Penicillium sp., Stagonospora nodorum, Phoma lingam, Alternaria sp., Botrytis cinerea, Rhizopus sp., Verticillium dahliae, Verticillium longisporum, Xanthomonas campestris pv. campestris, Fusarium oxysporum, Alternaria brassicae, Epicoccum sp., Fusarium culmorum, Pectobacterium sp., Colletotrichum coccodes, Gaeumannomyces graminis, Aspergillus niger, Septoria tritici, and Pyrenopeziza brassicae) (Table 1).

Plant DNA samples. Soybean (Glycine max L.) and oilseed rape (OSR, Brassica napus) DNA were extracted from healthy seedlings. DNA from wheat (Triticum aestivum L.), beans (Phaseolus vulgaris L.), oat (Avena spp.), OSR (Brassica sp.), barley (Hordeum vulgare L.), and potato tuber (Solanum tuberosum L.) were obtained from the NIAB DNA collection (Table 1).

Culture conditions and DNA extraction. Mycelia were obtained from the sclerotia and pure culture discs of fungal strains grown at room temperature in potato dextrose broth in an orbital shaker for approximately 5 days. The developed mycelia were collected by filtration using sterilized germitest paper and were then lyophilized. Trifoliates and leaves from healthy soybean and OSR seedlings cultivated on sterilized substrate were cleaned in ultrapure sterilized water. The lyophilized mycelia, soybean plant material, and tegument of soybean seeds infected by $P$. manshurica were macerated using a porcelain mortar and pestle with liquid nitrogen for DNA extraction. The DNA was extracted using the cetyltrimethylammonium bromide (CTAB) method as described by Ferreira and Grattapaglia (1998), with the exception that $\beta$-mercaptoethanol and PVP-40 were not used in the present study. All the DNA samples were treated with ribonuclease A $(10 \mu \mathrm{g} / \mathrm{ml})$ (Sigma-Aldrich, U.S.A.), diluted in TrisEDTA (TE) buffer (10 mM Tris-Cl, pH 8.0; and $1 \mathrm{mM}$ EDTA, pH 8.0 ) to $10 \mathrm{ng} / \mu \mathrm{l}$ and stored at $-20^{\circ} \mathrm{C}$ until use (Sambrook and Russell 2001). S. minor and OSR DNA were extracted using a NucleoSpin Tissue kit (Macherey-Nagel, Germany). To test the ability to detect $S$. sclerotiorum by LAMP without a complete DNA extraction, approximately $0.2 \mathrm{mg}$ of $S$. sclerotiorum sclerotia and $0.1 \mathrm{mg}$ of mycelium were collected from a pure culture of the standard isolate I-45 (cataloged in Culture Collection of Phytopathogenic Fungi Prof. Maria Menezes $[\mathrm{CMM}]$ as CMM-2030) and heated with $100 \mu \mathrm{l}$ of TE buffer at $95^{\circ} \mathrm{C}$ for $10 \mathrm{~min}$.

PCR specific to $S$. sclerotiorum. The DNA of the 57 isolates of $S$. sclerotiorum was amplified with SsFWD/SsREV (Freeman et al. 2002) (results published by Grabicoski et al. 2015) and SsF/SsR primer sets (Yin et al. 2009) to verify the species designation. The SsF/SsR PCR amplification was performed with ultrapure water (Sigma-Aldrich) in $20-\mu l$ reactions containing $1 \mathrm{U}$ of FastStart Taq DNA polymerase, $1 \mathrm{X}$ PCR reaction buffer with $\mathrm{MgCl}_{2}$ (Roche Diagnostics, Germany), $500 \mu \mathrm{M}$ of each primer, ultrapure water, and the DNA samples (50 ng of each isolate). No DNA reaction was used as a negative control. The PCR conditions consisted of an initial step at $92^{\circ} \mathrm{C}$ for $5 \mathrm{~min} ; 35$ cycles at $95^{\circ} \mathrm{C}$ for $30 \mathrm{~s}, 55^{\circ} \mathrm{C}$ for $30 \mathrm{~s}$, and $72^{\circ} \mathrm{C}$ for $30 \mathrm{~s}$; and a final extension at $72^{\circ} \mathrm{C}$ for $7 \mathrm{~min}$. The reactions were kept at $4{ }^{\circ} \mathrm{C}$ until they were used. The reaction products were analyzed on $1 \%$ agarose gels stained with $0.1 \mu \mathrm{g}$ of ethidium bromide per milliliter of gel, which were run for $1 \mathrm{~h}$ at $100 \mathrm{~V}$ and visualized in UV light (Sambrook and Russell 2001).

PCR to rDNA region. To evaluate the amplification quality of fungal DNA extracted in this study and from LAPP-UEPG, the ITS4 (5'-TCCTCCGCTTATTGATATGC- $\left.3^{\prime}\right)$ and ITS5 (5'GGAAGTAAAAGTCGTAACAAGG-3') primer pair was used, which binds to the internal transcribed spacer (ITS) region of the rDNA sequence (White et al. 1990). Each PCR amplification was performed as previously described for the SsF/SsR primer set, using $10 \mathrm{ng}$ of DNA as the sample. The reaction conditions consisted of an initial step at $95^{\circ} \mathrm{C}$ for $10 \mathrm{~min} ; 30$ cycles at $94^{\circ} \mathrm{C}$ for $30 \mathrm{~s}, 42^{\circ} \mathrm{C}$ for $2 \mathrm{~min}$, and $72^{\circ} \mathrm{C}$ for $2 \mathrm{~min}$; and a final cycle at $72^{\circ} \mathrm{C}$ for $10 \mathrm{~min}$ (White et al. 1990). To analyze the PCR amplification, $2 \mu l$ of the PCR reaction was mixed with $6 \mu 1$ of loading buffer $(0.25 \%$ bromophenol, 30\% glycerol in distilled water, GelRed 15X [Biotium, U.S.A.]), and this mixture was loaded on a $1 \%$ agarose gel in $1 \mathrm{X}$ Tris-borate-EDTA buffer (Sambrook and Russell 2001). I-45 isolate DNA was used as a positive control, and a reaction containing no template DNA was used as a negative control.

LAMP primer design. Six specific LAMP primers were designed based on the S. sclerotiorum hypothetical protein sequence (XM_ 001597857.1). The SsF and SsR primers described by Yin et al. (2009) as specific for S. sclerotiorum were used as the displacement primers (F3 and B3, respectively), and the region between them was used to design the others, as seen in Figure 1. Information regarding the primer names and sequences is provided in Table 2. A BLAST search was performed with the NCBI GenBank to test the similarity of the primer sequences with DNA sequences of other plant pathogens and some $S$. sclerotiorum host plants.

Evaluation of primer set Ss-LAMP. Temperature gradient tests were performed in $10-\mu l$ reactions containing $60 \%$ isothermal master mix (ISO-001, OptiGene, U.K.) used in accordance with the manufacturer's recommendations, $10 \mathrm{ng}$ of isolate I-45 DNA, and 0.2 , 0.4 , and $0.8 \mu \mathrm{M}$ concentrations of outer, loop, and inner primers, respectively (Nagamine et al. 2002; Notomi et al. 2000). The reactions were incubated for $60 \mathrm{~min}$ using a Genie II instrument (OptiGene), which gives real-time results using a temperature gradient from 60 to $65^{\circ} \mathrm{C}$ followed by a dissociation curve of the amplified product between 80 and $95^{\circ} \mathrm{C}$. Speed, specificity, amplification, and dissociation curve characteristics were considered in order to choose the best temperature. With the selected temperature $\left(65^{\circ} \mathrm{C}\right)$, all S. sclerotiorum isolates and all the other fungal DNA isolates (all from LAPPUEPG, except $S$. minor) were analyzed as described in the temperature test with 30 -min incubation periods.

Optimization of real-time LAMP protocol. Although commercial master mixes are more convenient, modifying the proportions of reagents in them is not possible. Commercial master mixes are more expensive, and in some cases, there is insufficient information available about the composition in the packaging. Therefore, we optimized a protocol using custom reagents for S. sclerotiorum with a real-time analysis LAMP method that we referred to as qLAMP (quantitative LAMP) and a protocol that allowed direct visual analysis that we referred to as cLAMP (calcein LAMP). As a starting point, a $25-\mu$ l LAMP reaction was used with $0.2,0.4$, and $0.8 \mu \mathrm{M}$ of outer, loop, and inner primers, respectively, $400 \mu \mathrm{M}$ of each dNTP, 1X isothermal amplification buffer $(20 \mathrm{mM}$ Tris- $\mathrm{HCl}$, $10 \mathrm{mM} \mathrm{KCl}, 10 \mathrm{mM}\left(\mathrm{NH}_{4}\right)_{2} \mathrm{SO}_{4}, 4 \mathrm{mM} \mathrm{MgSO}_{4}$, and $0.1 \%$ Triton $\mathrm{X}-100$ ), $8 \mathrm{U}$ of $B$. stearothermophilus (New England Biolabs, U.S.A.) (Nagamine et al. 2002; Notomi et al. 2000), and $1 X$ reference dye (Sigma-Aldrich). The reactions were incubated at the previously selected temperature $\left(65^{\circ} \mathrm{C}\right)$ for 40 to $60 \mathrm{~min}$, and the final amplified product was assessed using the dissociation curve from 65 to $95^{\circ} \mathrm{C}$. To choose the best concentration of each optimized reagent, the speeds of starting and finishing the amplification, the specificity, the nonspecific product formation, and the amplification and dissociation curve shapes were analyzed. An Agilent Mx Pro 3005P (Agilent Technologies, U.S.A.) was used for these steps.

EvaGreen 20X (Biotium) was selected as the DNA intercalating fluorescent dye for the reaction, and positive (10 $\mathrm{ng}$ of I-45 isolate DNA) and negative (no DNA) reactions were analyzed with EvaGreen concentrations of $0,0.5,1.0,1.5$, and $2.0 X(0.5 X=1.33 \mu \mathrm{M})$.

Once the EvaGreen concentration was selected, dNTP and primer concentrations were optimized, because dNTPs and primers are intimately related to amplification success. Four sets of primer concentrations $(0.8,0.4$, and $0.2 \mu \mathrm{M} ; 1.2,0.6$, and $0.3 \mu \mathrm{M} ; 1.6,0.8$, and $0.4 \mu \mathrm{M}$; and 2.0, 0.4, and $0.2 \mu \mathrm{M}$ for inner, loop, and, outer primers, respectively) and three dNTP concentrations $(0.4,0.8$, and $1.2 \mathrm{mM})$ were tested, resulting in 12 different combinations. Two reactions 
Table 1. Description of the DNA samples (Sclerotinia sclerotiorum isolates, other plant pathogens, and plants) used, as well as the results of PCR amplification (using primers SsFWD/SsREV, SsF/SsR, and ITS4/ITS5), and Ss-LAMP tests (Ss-qLAMP) with these samples

\begin{tabular}{|c|c|c|c|c|c|c|c|}
\hline \multirow[b]{2}{*}{ Sample $^{\mathbf{a}}$} & \multirow[b]{2}{*}{ Species } & \multirow[b]{2}{*}{ Locality (source) } & \multirow[b]{2}{*}{ Collector $(\text { Year })^{\mathbf{b}}$} & \multicolumn{3}{|c|}{$\mathbf{P C R}^{\mathbf{c}}$} & \multirow[b]{2}{*}{ Ss-LAMPc } \\
\hline & & & & SsFWD/SsREV ${ }^{d}$ & SsF/SsR & $\overline{\text { ITS4/ITS5 }}$ & \\
\hline $\mathrm{I}-01$ & S. sclerotiorum & Palmeira - PR & $1(09)$ & $(+)$ & $(+)$ & (N/A) & $(+)$ \\
\hline $\mathrm{I}-02$ & S. sclerotiorum & Carambeí - PR & $1(09)$ & $(+)$ & $(+)$ & (N/A) & $(+)$ \\
\hline $\mathrm{I}-03$ & S. sclerotiorum & Teixeira Soares - PR & $1(09)$ & $(+)$ & $(+)$ & (N/A) & $(+)$ \\
\hline I-04 & S. sclerotiorum & Honório Serpa - PR & $1(09)$ & $(+)$ & $(+)$ & (N/A) & $(+)$ \\
\hline $\mathrm{I}-05$ & S. sclerotiorum & Mangueirinha - PR & $1(09)$ & $(+)$ & $(+)$ & (N/A) & $(+)$ \\
\hline I-06 & S. sclerotiorum & Pinhão - PR & $1(09)$ & $(+)$ & $(+)$ & (N/A) & $(+)$ \\
\hline $\mathrm{I}-07$ & S. sclerotiorum & Ivaí - PR & $1(09)$ & $(+)$ & $(+)$ & (N/A) & $(+)$ \\
\hline $\mathrm{I}-08$ & S. sclerotiorum & Piraí do Sul - PR & $1(09)$ & $(+)$ & $(+)$ & (N/A) & $(+)$ \\
\hline I-09 & S. sclerotiorum & Pinhão - PR & $1(09)$ & $(+)$ & $(+)$ & (N/A) & $(+)$ \\
\hline $\mathrm{I}-10$ & S. sclerotiorum & Ipiranga - PR & $1(09)$ & $(+)$ & $(+)$ & (N/A) & $(+)$ \\
\hline $\mathrm{I}-11$ & S. sclerotiorum & Palmeira - PR & $1(09)$ & $(+)$ & $(+)$ & (N/A) & $(+)$ \\
\hline $\mathrm{I}-12$ & S. sclerotiorum & Palmeira - PR & $1(09)$ & $(+)$ & $(+)$ & (N/A) & $(+)$ \\
\hline $\mathrm{I}-13$ & S. sclerotiorum & Pinhão - PR & $1(09)$ & $(+)$ & $(+)$ & (N/A) & $(+)$ \\
\hline $\mathrm{I}-14$ & S. sclerotiorum & Carambeí - PR & $1(09)$ & $(+)$ & $(+)$ & (N/A) & $(+)$ \\
\hline $\mathrm{I}-15$ & S. sclerotiorum & Guarapuava - PR & $1(09)$ & $(+)$ & $(+)$ & (N/A) & $(+)$ \\
\hline $\mathrm{I}-16$ & S. sclerotiorum & Pinhão - PR & $1(09)$ & $(+)$ & $(+)$ & (N/A) & $(+)$ \\
\hline $\mathrm{I}-17$ & S. sclerotiorum & Prudentópolis - PR & $1(09)$ & $(+)$ & $(+)$ & (N/A) & $(+)$ \\
\hline $\mathrm{I}-18$ & S. sclerotiorum & Palmeira - PR & $1(09)$ & $(+)$ & $(+)$ & (N/A) & $(+)$ \\
\hline $\mathrm{I}-19$ & S. sclerotiorum & Teixeira Soares - PR & $1(09)$ & $(+)$ & $(+)$ & (N/A) & $(+)$ \\
\hline $\mathrm{I}-20$ & S. sclerotiorum & Ventania - PR & $1(09)$ & $(+)$ & $(+)$ & (N/A) & $(+)$ \\
\hline $\mathrm{I}-21$ & S. sclerotiorum & Mangueirinha - PR & $1(09)$ & $(+)$ & $(+)$ & (N/A) & $(+)$ \\
\hline $\mathrm{I}-22$ & S. sclerotiorum & Tibagi - PR & $1(09)$ & $(+)$ & $(+)$ & (N/A) & $(+)$ \\
\hline $\mathrm{I}-23$ & S. sclerotiorum & Teixeira Soares - PR & $1(09)$ & $(+)$ & $(+)$ & (N/A) & $(+)$ \\
\hline $\mathrm{I}-24$ & S. sclerotiorum & Prudentópolis - PR & $1(09)$ & $(+)$ & $(+)$ & (N/A) & $(+)$ \\
\hline $\mathrm{I}-25$ & S. sclerotiorum & Teixeira Soares - PR & $1(09)$ & $(+)$ & $(+)$ & (N/A) & $(+)$ \\
\hline $\mathrm{I}-26$ & S. sclerotiorum & Ventania - PR & $1(09)$ & $(+)$ & $(+)$ & (N/A) & $(+)$ \\
\hline $\mathrm{I}-27$ & S. sclerotiorum & Castrolanda - PR & $1(09)$ & $(+)$ & $(+)$ & (N/A) & $(+)$ \\
\hline $\mathrm{I}-28$ & S. sclerotiorum & Ponta Grossa - PR & $1(09)$ & $(+)$ & $(+)$ & (N/A) & $(+)$ \\
\hline $\mathrm{I}-29$ & S. sclerotiorum & Ipiranga - PR & $1(09)$ & $(+)$ & $(+)$ & (N/A) & $(+)$ \\
\hline $\mathrm{I}-30$ & S. sclerotiorum & Guaragi - PR & $1(09)$ & $(+)$ & $(+)$ & (N/A) & $(+)$ \\
\hline $\mathrm{I}-31$ & S. sclerotiorum & Palmeira - PR & $1(09)$ & $(+)$ & $(+)$ & (N/A) & $(+)$ \\
\hline $\mathrm{I}-32$ & S. sclerotiorum & Prudentópolis - PR & $1(09)$ & $(+)$ & $(+)$ & (N/A) & $(+)$ \\
\hline $\mathrm{I}-33$ & S. sclerotiorum & Ponta Grossa - PR & $1(09)$ & $(+)$ & $(+)$ & (N/A) & $(+)$ \\
\hline $\mathrm{I}-34$ & S. sclerotiorum & Pinhão - PR & $1(09)$ & $(+)$ & $(+)$ & (N/A) & $(+)$ \\
\hline $\mathrm{I}-35$ & S. sclerotiorum & Tibagi - PR & $1(09)$ & $(+)$ & $(+)$ & (N/A) & $(+)$ \\
\hline $\mathrm{I}-36$ & S. sclerotiorum & Palmeira - PR & $1(09)$ & $(+)$ & $(+)$ & (N/A) & $(+)$ \\
\hline $\mathrm{I}-37$ & S. sclerotiorum & Ventania - PR & $1(09)$ & $(+)$ & $(+)$ & (N/A) & $(+)$ \\
\hline $\mathrm{I}-38$ & S. sclerotiorum & Mangueirinha - PR & $1(09)$ & $(+)$ & $(+)$ & (N/A) & $(+)$ \\
\hline $\mathrm{I}-39$ & S. sclerotiorum & Mangueirinha - PR & $1(09)$ & $(+)$ & $(+)$ & (N/A) & $(+)$ \\
\hline $\mathrm{I}-40$ & S. sclerotiorum & Palmas - PR & $1(09)$ & $(+)$ & $(+)$ & (N/A) & $(+)$ \\
\hline $\mathrm{I}-41$ & S. sclerotiorum & Palmeira - PR & $1(09)$ & $(+)$ & $(+)$ & (N/A) & $(+)$ \\
\hline $\mathrm{I}-42$ & S. sclerotiorum & Mangueirinha - PR & $1(09)$ & $(+)$ & $(+)$ & (N/A) & $(+)$ \\
\hline $\mathrm{I}-43$ & S. sclerotiorum & Ponta Grossa - PR & $2(11)$ & $(+)$ & $(+)$ & (N/A) & $(+)$ \\
\hline $\mathrm{I}-44$ & S. sclerotiorum & Formosa - GO & $3(10)$ & $(+)$ & $(+)$ & (N/A) & $(+)$ \\
\hline $\mathrm{I}-45$ & S. sclerotiorum & Jataí - GO & $4(09)^{*}$ & $(+)$ & $(+)$ & (N/A) & $(+)$ \\
\hline $\mathrm{I}-46$ & S. sclerotiorum & L. E. Magalhães - BA & $5(10)$ & $(+)$ & $(+)$ & (N/A) & $(+)$ \\
\hline $\mathrm{I}-47$ & S. sclerotiorum & Maringá - PR & $6(10)^{*}$ & $(+)$ & $(+)$ & (N/A) & $(+)$ \\
\hline \multirow[t]{2}{*}{$\mathrm{I}-48$} & S. sclerotiorum & Arino - MG & $7(10)$ & $(+)$ & $(+)$ & (N/A) & $(+)$ \\
\hline & & & & & & \multicolumn{2}{|c|}{ (Continued on next page) } \\
\hline
\end{tabular}

a DNA samples used in the present study. S. sclerotiorum isolates/samples: I-01 to I-48: collected from a soybean (G. max) field (soil samples); I-49: collected from a bean (P. vulgaris) field; I-50: collected from a sunflower (Helianthus annuus) field; I-51: collected from a brassica plant (Brassica oleracea L.); I-52: collected from a weed plant (Potentilla anserina L.); I-53: collected from a cabbage (B. oleracea var. capitata L.) field (plants); I-54: collected from a weed plant (Sonchus oleraceus L.); I-55: collected from a lettuce (Lactuca sativa L.) field (plants); I-56: collected from a parsley (Petroselinum crispum [Mill.] Nym) field; and I-57: collected from an oilseed rape (B. napus L.) field (plants). S. sclerotiorum official collection codes (Collection of Phytopathogenic Fungi Prof. Maria Menezes): I-01 (CMM-1461); I-02 (CMM-1774); I-03 (CMM-0093); I-04 (CMM-1776); I-05 (CMM-0094); I-08 (CMM-0096); I-10 (CMM-1526); I-11 (CMM-0098); I-12 (CMM-0105); I-13 (CMM-0106); I-14 (CMM-1786); I-16 (CMM-1788); I-18 (CMM-1794); I-22 (CMM-1554); I-24 (CMM-1562); I-25 (CMM-1563); I-26 (CMM-0107); I-28 (CMM-1801); I-29 (CMM-1803); I-30 (CMM-1804); I-32 (CMM-1564); I-34 (CMM-1566); I-37 (CMM-1567); I-40 (CMM-0109); I-42 (CMM-0112); I-45 (CMM-2030); I-46 (CMM-1832); I-48 (CMM-1568); I-52 (CMM-1570); I-54 (CMM-1571); I-55 (CMM-0113); and I-57 (CMM-1574). OF-BR: Other, non-S. sclerotiorum, fungal species from a Brazilian collection (UEPG, Group of Applied Plant Pathology). OF-UK: Other, non-S. sclerotiorum, fungal species from a U.K. collection (NIAB, Cambridge, U.K.).

b Sample collector: 1 = Jaccoud-Filho et al. (UEPG); 2 = M. L. C. Pierre (UEPG); $3=$ C. Rosa (PIONEER); $4=$ R. A. Garcia and F. C. Juliatti (UFU); $5=$ R. M. Mercer (PIONEER); 6 = J. B. Vida (UEM); 7 = R. F. de Paula (PIONEER); $8=$ M. M. de Lima (PIONEER); $9=$ L. Henneberg (UEPG); 10 = C. M. Vrisman (UEPG); 11 = M. O. Manosso Neto (UEPG); 12 = E. M. G. Grabicoski (UEPG); 13 = A. Reis (CNPH-EMBRAPA); $14=$ H. Appleyard (NIAB, Cambridge, U.K.); 15 = C. L. Baran (UEPG); and 16 = NIAB Collection (Cambridge, U.K.). Year of collection: $(09)=2009 ;(10)=2010 ;(11)=2011 ;$ N/A = not available; and $*=$ year of collection is unknown, and the year of availability for the present research was considered.

c PCR and LAMP amplification results: $(+)=$ amplification detected; $(-)=$ no amplification detected; and (N/A) = not applicable.

${ }^{\mathrm{d}}$ Results published in Grabicoski et al. (2015). 
Table 1. (Continued from previous page)

\begin{tabular}{|c|c|c|c|c|c|c|c|}
\hline \multirow[b]{2}{*}{ Sample } & \multirow[b]{2}{*}{ Species } & \multirow[b]{2}{*}{ Locality (source) } & \multirow[b]{2}{*}{ Collector (Year) $)^{\mathbf{b}}$} & \multicolumn{3}{|c|}{$\mathbf{P C R}^{\mathbf{c}}$} & \multirow[b]{2}{*}{ Ss-LAMPc } \\
\hline & & & & SsFWD/SsREV & SsF/SsR & ITS4/ITS5 & \\
\hline $\mathrm{I}-49$ & S. sclerotiorum & Casa Branca - SP & $8(10)$ & $(+)$ & $(+)$ & (N/A) & $(+)$ \\
\hline $\mathrm{I}-50$ & S. sclerotiorum & Ipiranga - PR & $9(10)$ & $(+)$ & $(+)$ & (N/A) & $(+)$ \\
\hline $\mathrm{I}-51$ & S. sclerotiorum & Ponta Grossa - PR & $10(10)$ & $(+)$ & $(+)$ & (N/A) & $(+)$ \\
\hline $\mathrm{I}-52$ & S. sclerotiorum & Ventania - PR & $11(10)$ & $(+)$ & $(+)$ & (N/A) & $(+)$ \\
\hline $\mathrm{I}-53$ & S. sclerotiorum & Ponta Grossa - PR & $10(10)$ & $(+)$ & $(+)$ & (N/A) & $(+)$ \\
\hline $\mathrm{I}-54$ & S. sclerotiorum & Ponta Grossa - PR & $12(10)$ & $(+)$ & $(+)$ & (N/A) & $(+)$ \\
\hline $\mathrm{I}-55$ & S. sclerotiorum & Ponta Grossa - PR & $12(11)$ & $(+)$ & $(+)$ & (N/A) & $(+)$ \\
\hline $\mathrm{I}-56$ & S. sclerotiorum & Brasília-DF & $13(11)^{*}$ & $(+)$ & $(+)$ & (N/A) & $(+)$ \\
\hline $\mathrm{I}-57$ & S. sclerotiorum & Ipiranga - PR & $12(10)$ & $(+)$ & $(+)$ & (N/A) & $(+)$ \\
\hline SSNIAB & S. sclerotiorum & N/A & $14(\mathrm{~N} / \mathrm{A})$ & (N/A) & (N/A) & (N/A) & $(+)$ \\
\hline OF-BR & Cercospora sojina & N/A & 1 (N/A) & (N/A) & (N/A) & $(+)$ & $(-)$ \\
\hline OF-BR & Phomopsis sojae & N/A & $1(\mathrm{~N} / \mathrm{A})$ & (N/A) & (N/A) & $(+)$ & $(-)$ \\
\hline OF-BR & Aspergillus sp. & N/A & 1 (N/A) & (N/A) & (N/A) & $(+)$ & $(-)$ \\
\hline OF-BR & Cercospora kikuchii & N/A & 1 (N/A) & (N/A) & (N/A) & $(+)$ & $(-)$ \\
\hline OF-BR & Trichoderma sp. & Ponta Grossa - PR & $12(11)$ & (N/A) & (N/A) & $(+)$ & $(-)$ \\
\hline OF-BR & Penicillium sp. & Ponta Grossa - PR & $12(10)$ & (N/A) & (N/A) & $(+)$ & $(-)$ \\
\hline OF-BR & $\begin{array}{l}\text { Peronospora } \\
\text { manshurica }\end{array}$ & Ponta Grossa - PR & $12(10)$ & (N/A) & (N/A) & $(+)$ & $(-)$ \\
\hline OF-BR & Rhizopus sp. & Ponta Grossa - PR & $12(10)$ & (N/A) & (N/A) & $(+)$ & $(-)$ \\
\hline OF-BR & Aspergillus sp. & Ponta Grossa - PR & $12(10)$ & (N/A) & (N/A) & $(+)$ & $(-)$ \\
\hline OF-BR & Rhizoctonia solani & Ponta Grossa - PR & $12(11)$ & (N/A) & (N/A) & $(+)$ & $(-)$ \\
\hline OF-BR & Colletotrichum sp. & Ponta Grossa - PR & $12(11)$ & (N/A) & (N/A) & $(+)$ & $(-)$ \\
\hline OF-BR & $\begin{array}{l}\text { Macrophomina } \\
\text { phaseolina }\end{array}$ & Ponta Grossa - PR & $12(11)$ & (N/A) & (N/A) & $(+)$ & $(-)$ \\
\hline OF-BR & Sclerotium rolfsii & Ponta Grossa - PR & $1(09)$ & (N/A) & (N/A) & $(+)$ & $(-)$ \\
\hline OF-BR & Sclerotinia minor & N/A & $15(14)$ & (N/A) & (N/A) & $(+)$ & $(-)$ \\
\hline OF-BR & Alternaria sp. & Ponta Grossa - PR & $12(13)$ & (N/A) & (N/A) & $(+)$ & $(-)$ \\
\hline OF-BR & Cercospora sp. & Ponta Grossa - PR & $12(13)$ & (N/A) & (N/A) & $(+)$ & $(-)$ \\
\hline OF-UK & Rhizoctonia sp. & NIAB Collection & 14 (N/A) & (N/A) & (N/A) & (N/A) & $(-)$ \\
\hline OF-UK & Stemphylium sp. & NIAB Collection & 14 (N/A) & (N/A) & (N/A) & (N/A) & $(-)$ \\
\hline OF-UK & Penicillium sp. & NIAB Collection & 14 (N/A) & (N/A) & (N/A) & (N/A) & $(-)$ \\
\hline OF-UK & $\begin{array}{l}\text { Stagonospora } \\
\text { nodorum }\end{array}$ & NIAB Collection & $14(\mathrm{~N} / \mathrm{A})$ & (N/A) & (N/A) & (N/A) & $(-)$ \\
\hline OF-UK & Phoma lingam & NIAB Collection & 14 (N/A) & (N/A) & (N/A) & (N/A) & $(-)$ \\
\hline OF-UK & Alternaria sp. & NIAB Collection & 14 (N/A) & (N/A) & (N/A) & (N/A) & $(-)$ \\
\hline OF-UK & Botrytis cinerea & NIAB Collection & 14 (N/A) & (N/A) & (N/A) & (N/A) & $(-)$ \\
\hline OF-UK & Rhizopus sp. & NIAB Collection & 14 (N/A) & (N/A) & (N/A) & (N/A) & $(-)$ \\
\hline OF-UK & Verticillium dahliae & NIAB Collection & 14 (N/A) & (N/A) & (N/A) & (N/A) & $(-)$ \\
\hline OF-UK & Verticillium longisporum & NIAB Collection & 14 (N/A) & (N/A) & (N/A) & (N/A) & $(-)$ \\
\hline OF-UK & $\begin{array}{l}\text { Xanthomonas campestris } \\
\text { pv. campestris }\end{array}$ & NIAB Collection & $14(\mathrm{~N} / \mathrm{A})$ & (N/A) & (N/A) & (N/A) & $(-)$ \\
\hline OF-UK & Fusarium oxysporum & NIAB Collection & 14 (N/A) & (N/A) & (N/A) & (N/A) & $(-)$ \\
\hline OF-UK & Alternaria brassicae & NIAB Collection & 14 (N/A) & (N/A) & (N/A) & (N/A) & $(-)$ \\
\hline OF-UK & Epicoccum sp. & NIAB Collection & 14 (N/A) & (N/A) & (N/A) & (N/A) & $(-)$ \\
\hline OF-UK & Fusarium culmorum & NIAB Collection & 14 (N/A) & (N/A) & (N/A) & (N/A) & $(-)$ \\
\hline OF-UK & Pectobacterium sp. & NIAB Collection & 14 (N/A) & (N/A) & (N/A) & (N/A) & $(-)$ \\
\hline OF-UK & Verticillium dahliae & NIAB Collection & $14(\mathrm{~N} / \mathrm{A})$ & (N/A) & (N/A) & (N/A) & $(-)$ \\
\hline OF-UK & Verticillium dahliae & NIAB Collection & 14 (N/A) & (N/A) & (N/A) & (N/A) & $(-)$ \\
\hline OF-UK & Colletotrichum coccodes & NIAB Collection & $14(\mathrm{~N} / \mathrm{A})$ & (N/A) & (N/A) & (N/A) & $(-)$ \\
\hline OF-UK & $\begin{array}{l}\text { Gaeumannomyces } \\
\text { graminis }\end{array}$ & NIAB Collection & $14(\mathrm{~N} / \mathrm{A})$ & (N/A) & (N/A) & (N/A) & $(-)$ \\
\hline OF-UK & Aspergillus niger & NIAB Collection & $14(\mathrm{~N} / \mathrm{A})$ & (N/A) & (N/A) & (N/A) & $(-)$ \\
\hline OF-UK & Septoria tritici & NIAB Collection & 14 (N/A) & (N/A) & (N/A) & (N/A) & $(-)$ \\
\hline OF-UK & Pyrenopeziza brassicae & NIAB Collection & 14 (N/A) & (N/A) & (N/A) & (N/A) & $(-)$ \\
\hline Soybean & $\begin{array}{l}\text { Soybean } \\
\text { (Glycine } \max \mathrm{L} .)\end{array}$ & Ponta Grossa - PR & $12(09)$ & (N/A) & (N/A) & (N/A) & $(-)$ \\
\hline Oilseed rape & $\begin{array}{l}\text { Brassica napus var. } \\
\quad \text { oleifera }\end{array}$ & Ponta Grossa - PR & $12(13)$ & (N/A) & (N/A) & (N/A) & $(-)$ \\
\hline Wheat & Triticum aestivum & Cambridge - UK & 16 (N/A) & (N/A) & (N/A) & (N/A) & $(-)$ \\
\hline Bean & $\begin{array}{l}\text { Phaseolus vulgaris L., } \\
\text { cv. Fuego }\end{array}$ & Cambridge - UK & $16(\mathrm{~N} / \mathrm{A})$ & (N/A) & (N/A) & (N/A) & $(-)$ \\
\hline Oat & Avena spp., cv. Rozmar & Cambridge - UK & $16(\mathrm{~N} / \mathrm{A})$ & (N/A) & (N/A) & (N/A) & $(-)$ \\
\hline Oilseed rape & Brassica spp. & Cambridge - UK & 16 (N/A) & (N/A) & (N/A) & (N/A) & $(-)$ \\
\hline Barley & $\begin{array}{l}\text { Hordeum vulgare L., } \\
\text { cv. Propino }\end{array}$ & Cambridge - UK & $16(\mathrm{~N} / \mathrm{A})$ & (N/A) & (N/A) & (N/A) & $(-)$ \\
\hline Potato & Solanum tuberosum L. & Cambridge - UK & $16(\mathrm{~N} / \mathrm{A})$ & (N/A) & (N/A) & (N/A) & $(-)$ \\
\hline
\end{tabular}


were conducted for each combination, one with no DNA (negative control) and another with $10 \mathrm{ng}$ of I-45 isolate (positive control).

Betaine and $\mathrm{MgCl}_{2}$ concentrations were then optimized. Four betaine concentrations $(0,0.5,1.0$, and $1.5 \mathrm{M})$ were analyzed with two $\mathrm{MgCl}_{2}$ concentrations ( 0 and $2 \mathrm{mM}$ ), totalizing eight combinations. Ten nanograms of isolate I-45 DNA was used as a positive control, and $10 \mathrm{ng}$ of $S$. minor DNA was used as a negative control.

The specificity of conditions (1.5X EvaGreen; $0.8,0.4$, and $0.2 \mu \mathrm{M}$ of primers; $0.4 \mathrm{mM}$ of dNTPs; $0.5 \mathrm{M}$ of betaine; and no extra $\mathrm{MgCl}_{2}$ ) was tested using $10 \mathrm{ng}$ of DNA from all microorganisms and plants included in the study.

Direct amplification of fungi samples. To test the ability to directly apply crude samples in the reaction without DNA purification steps, and to evaluate the sensitivity using these types of samples, $1 \mu \mathrm{l}$ of a mycelium suspension (10 mg of mycelium in $100 \mu \mathrm{l}$ of TE buffer, heated at $95^{\circ} \mathrm{C}$ for $10 \mathrm{~min}$ ) was amplified in the optimized qLAMP reaction (10 $\mu$ l total volume) in duplicate.

Sensitivity and standard curves for qLAMP. DNA (100 ng to 1 $\mathrm{fg}$ ) and mycelium (1 mg to $1 \mathrm{fg}$ ) samples of isolate I- 45 were serially diluted 10 times and tested with the optimized qLAMP reaction for $S$. sclerotiorum. Each reaction was performed in duplicate. Five consecutive dilutions of each DNA and mycelium that were amplified were taken to obtain a standard curve and to enable quantification (Bustin et al. 2009; Heid et al. 1996). The quantitation using informative zeros (QUIZ) method (Lee et al. 2010) was also used to estimate the detection limit of the qLAMP protocol by dividing 200, 170, and $100 \mu \mathrm{l}$ of reaction mixture into 50 reactions of $4 \mu \mathrm{l}$, and 170 and 100 reactions of $1 \mu l$, respectively.

cLAMP. To evaluate the use of calcein in the reaction to enable visualization of results, the reaction was performed on a $25-\mu 1$ scale using the reagents as described by Tomita et al. (2008). The primer concentration used was initially optimized $(0.8 \mu \mathrm{M}$ of SsFIP and SsBIP, $0.4 \mu \mathrm{M}$ of SsLoop primers, and $0.2 \mu \mathrm{M}$ of the SsF3 and SsB3 primers), and a series of dNTP concentrations were evaluated $(0,0.4,0.6,0.8,1.0,1.2$, and $1.4 \mathrm{mM})$ using a negative (water) and positive (10 ng of I-45) control reaction. The selected dNTP concentration $(1.2 \mathrm{mM})$ was used in the specificity and sensitivity experiments. All cLAMP reactions were incubated at $65^{\circ} \mathrm{C}$ for $40 \mathrm{~min}$. After incubation, the tubes were analyzed with the naked eye (pink = negative, and green $=$ positive amplification), under UV light (dull = negative, and bright $=$ positive amplification), and in $1 \%$ agarose gels analyzed using GelRed (Biotium) as the DNA dye (Sambrook and Russell 2001) (no bands $=$ negative, and ladder like profile $=$ positive amplification $)$.
cLAMP specificity test. Ten-nanogram DNA samples of all other fungi, as well as soybean and OSR, were tested using the proposed assay.

cLAMP sensitivity test. Ten times serial dilutions of I-45 isolate DNA solution were used (100 $\mathrm{ng}$ to $1 \mathrm{fg}$ ) in duplicate for each concentration.

Specific detection and quantification of $S$. sclerotiorum in soil samples by Ss-qLAMP. Artificially inoculated soil samples were created with $0.25 \mathrm{~g}$ of dried sterilized soil by adding $12.5 \mu \mathrm{l}$ of $S$. sclerotiorum mycelium suspensions containing $0.2 \mathrm{mg}$ of fresh mycelium (grown in potato dextrose broth) per microliter of sterile distilled water (equivalent to $20 \mu \mathrm{g} / \mu \mathrm{l}$ of air-dried mycelium, or a total of $250 \mu \mathrm{g}$ or one part dried mycelium to 1,000 parts dried soil per soil sample). The DNA extractions were attempted using five different protocols. In the first (i; labeled SDS), samples were added to 2.0$\mathrm{ml}$ tubes containing three metal balls (tungsten carbide beads, $3 \mathrm{~mm}$ ), $600 \mu \mathrm{l}$ of sodium dodecyl sulfate (SDS), and 2\% buffer. Soil samples were shaken in a TissueLyser II (Qiagen, Germany) machine for $10 \mathrm{~min}$ at maximum power, and the supernatants were transferred to new tubes. Ten percent of the volume of potassium acetate $3 \mathrm{M}$ (around $60 \mu \mathrm{l}$ ) was added, and the samples were vortexed and then spun for $1 \mathrm{~min}$. The resulting supernatant was transferred to a NucleoSpin Plant II filter column tube (Macherey-Nagel) according to the manufacturer's recommendation, and $50 \mu \mathrm{l}$ of TE buffer was used for DNA elution. In the second (ii; SDS+PVPP), the same protocol as " $i$ " was followed, but a $4 \%$ polyvinylpolypyrrolidone (PVPP) buffer was added in the SDS in the first step. In the third (iii; CTAB), samples were added to 2.0-ml tubes containing three metal balls and the previously described CTAB buffer. Samples were shaken in a TissueLyser II (Qiagen) machine for $10 \mathrm{~min}$ at maximum power, and following steps proceeded as described for the fungal DNA samples using $50 \mu \mathrm{l}$ of TE buffer to resuspend the DNA. In the fourth (iv; $\mathrm{CTAB}+\mathrm{PVPP}$ ), the same procedure was followed as for CTAB (i.e., "iii"), but $2 \%$ PVPP was included with the CTAB buffer in the first step. In the fifth (v; PowerSoil), the PowerSoil DNA extraction kit (Mo Bio Laboratories, U.S.A.) was used as recommended by the manufacturer, and the TissueLyser II was also integrated into the procedure. All eluted DNA samples were analyzed with the qLAMP reaction in three 10 -fold dilutions $\left(10^{0}, 10^{-1}\right.$, and $\left.10^{-2}\right)$. The qLAMP reactions were conducted using a commercial master mix (OptiGene) following the manufacturer's instructions, and with the optimized primer and betaine concentrations, and time and temperature as previously described, in $10-\mu l$ reactions and using $10 \%$ of samples per reaction (eluted and diluted DNA from the extractions). Results were

A

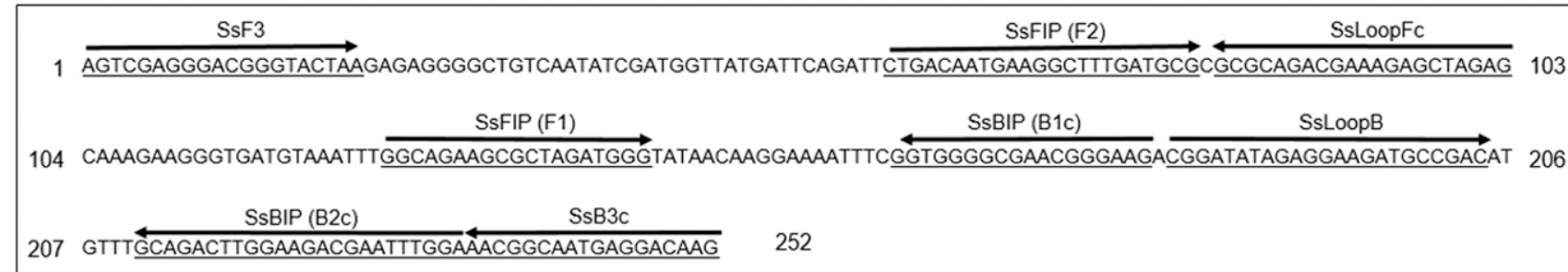

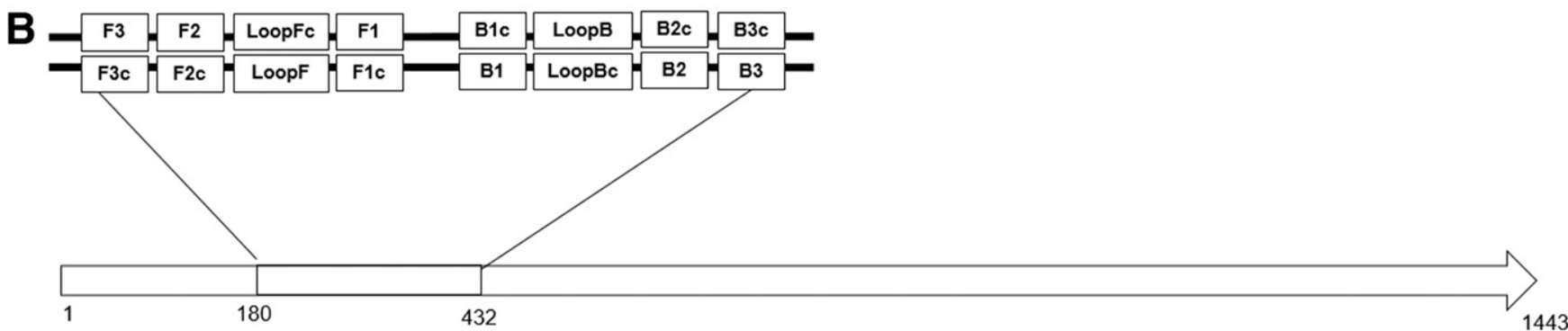

Fig. 1. Design of LAMP primers for Sclerotinia sclerotiorum detection. A, Nucleotide sequence alignment of primers with the S. sclerotiorum target region. Bold arrows indicate the sequences used for Ss-LAMP primers. B, Schematic representation of the Ss-LAMP primer sequences used in the hypothetical protein sequence (GenBank XM_001597857.1). 
obtained using real-time curves (StepOne Real-Time PCR System, Applied Biosystems, Fisher Scientific, Canada) and agarose gels. Positive (10 ng of I-45 DNA), negative (no DNA), and mycelium suspension in 10-fold dilution from $20 \mu \mathrm{g}$ to $200 \mathrm{fg}$ were also included. The last set of mycelia samples were used to construct a standard curve. The amplification and melting curve for all reactions were used to detect and confirm the specific presence of S. sclerotiorum and its quantification. The reactions of the eluted and diluted DNA samples extracted from soil were also analyzed by agarose gels (as described previously).

Specific identification/detection of $S$. sclerotiorum in plant tissue by direct visual analysis using cLAMP reaction. Six samples of plant tissue (soybean) naturally infected with S. sclerotiorum based on visible symptoms and signals were used. Pieces of 1 to $2 \times 2$ to $5 \mathrm{~mm}$ of diseased tissue (pods and internal and external stem tissues, two of each) were collected and added to microtubes, one piece per tube. Identical samples from healthy soybean tissue were also collected. To half of the tubes, $100 \mu \mathrm{l}$ of TE buffer was added; the tubes were heated at $95^{\circ} \mathrm{C}$ for $10 \mathrm{~min}$ and then kept in ice until they were used in the cLAMP reaction. For the other half of the tubes, DNA extractions were performed using the CTAB protocol described previously, except a micropistil was used to crush the plant tissues. The optimized cLAMP reactions were performed as previously described using $2 \mu \mathrm{l}$ of the TE buffer-tube samples or $20 \mathrm{ng}$ of the DNA extracted with the CTAB method. The reactions were made in duplicate with positive (10 ng of $S$. sclerotiorum I-45 isolate DNA) and negative controls (both no DNA and healthy plant tissue). The specific SsF/SsR PCR protocol was also used for comparison. The results were validated on agarose gels (as described previously) and directly visualized.

\section{Results}

Temperature optimization. There were almost no differences within the range of 60 to $65^{\circ} \mathrm{C}$ for the proposed LAMP amplification reaction (results not shown). The higher the temperature, the higher the stringency of the amplification (Innis et al. 1990), and $65^{\circ} \mathrm{C}$ was selected for further steps.

Primer-set sensitivity and specificity for S. sclerotiorum. According to the PCR amplification using the SsF/SsR primer set, a 252-bp specific fragment was amplified from all the isolates, thereby confirming the presence of $S$. sclerotiorum (Table 1). Further, all isolates that were amplified using the proposed LAMP reaction and the primer set Ss-LAMP (Table 1) produced an $87^{\circ} \mathrm{C}$ product in the dissociation curve analysis (results not shown). DNA from no other species (that was available at that moment) was amplified (Table 1).

Optimization of Ss-qLAMP reaction with a custom mix. With the specificity of the Ss-LAMP primer set confirmed using a commercial master mix for LAMP (OptiGene), the following analyses were carried out to optimize the master mix for use in any conditions.

Fluorescence dye (EvaGreen) concentration. After normalization, the EvaGreen dye concentration test indicated that $0.5 \mathrm{X}$ and $1.0 \mathrm{X}$ concentrations produced amplification curves with the best shapes (with a high fluorescence level) and the highest final fluorescence levels of all the tested concentrations. Contrary to expectations, the

Table 2. Name and sequence of primers designed specifically for Sclerotinia sclerotiorum and the LAMP method (Ss-LAMP primer set)

\begin{tabular}{lc}
\hline Primer name & \multicolumn{1}{c}{ Sequence $\left(\mathbf{5}^{\prime}-\mathbf{3}^{\prime}\right)$} \\
\hline SsF3 $(\mathrm{SsF})^{\mathrm{a}}$ & AGTCGAGGGACGGGTACTAA \\
SsB3 $(\mathrm{SsR})^{\mathrm{a}}$ & CTTGTCCTCATTGCCGTTT \\
SsFIP $(\mathrm{F} 1 \mathrm{c}+\underline{\mathrm{F} 2})$ & CCCATCTAGCGCTTCTGCC- \\
SsBIP $(\mathrm{B} 1 \mathrm{c}+\underline{\mathrm{B} 2})$ & CTGACAATGAAGGCTTTGATGCG \\
SsLoop F & CCAAATTCGTCTTCCAAGTCTGC \\
SsLoop B & CTCTAGCTCTTTCGT CTGCGC \\
\hline
\end{tabular}

a Source: Yin et al. (2009).
2.0X concentration produced an irregular curve and did not yield the greatest fluorescence level, suggesting amplification inhibition. The $0.5 \mathrm{X}$ EvaGreen concentration was selected as the best, and because primer-dimer formation was observed, further optimization steps were required (Supplementary Fig. S1).

Primer and dNTP concentrations. The negative control for the primer combinations (2.0:0.4:0.2 with dNTPs at $0.4 \mathrm{mM}$ ) produced primer-dimers products, which was probably due to the high FIP/ BIP primer concentration. In the reactions with the 1.2:0.6:0.3 $\mu \mathrm{M}$ primer concentrations and a $0.8 \mathrm{mM}$ dNTP concentration, as well as the others in the sequence with high concentration of such reagents, no amplification was observed, which was likely due to a high concentration of these reagents, resulting in the inhibition of the reaction (Supplementary Fig. S1).

Due to factors such as beginning and ending amplification speeds, the final quantity of the amplified product, the shape of the amplification curve, and the absence of nonspecific products and primerdimer formations, 0.8:0.4:0.2 $\mu \mathrm{M}$ primer concentrations and a $0.4 \mathrm{mM}$ dNTP concentration were selected.

Betaine and $\mathrm{MgCl}_{2}$ concentrations. Higher betaine concentrations produced fewer and later nonspecific amplification products in the non-S. sclerotiorum samples. Increasing the magnesium chloride concentration resulted in a decrease in specificity (Supplementary Fig. S2). A $1 \mathrm{M}$ betaine concentration with no extra magnesium chloride and a reaction time of $40 \mathrm{~min}$ (not $60 \mathrm{~min}$ as before) were selected as standards and used for further reactions.

Ss-qLAMP specificity. The Ss-qLAMP reaction was analyzed with a larger panel of other (i.e., non-S. sclerotiorum) DNA, which included many plant pathogens (36) and plant DNA (eight). With no optimization (no betaine and $60 \mathrm{~min}$ of reaction incubation), some plant pathogens' DNA amplified (Supplementary Fig. S3A). After the optimization steps, no amplification was observed (Supplementary Fig. S3B to D), demonstrating the specificity of the assay. Many DNA samples from important $S$. sclerotiorum hosts were analyzed with the Ss-qLAMP reaction, such as soybean, OSR, bean, and potato, and no amplification was detected (Table 1). According to the BLAST search with other possible hosts, such as lettuce, sunflower, carrot, and cotton, no similarity was detected with the Ss-LAMP primer sequences (data not shown).

Direct fungal detection with no DNA extraction steps, sensitivity, and standard curves for Ss-qLAMP with $S$. sclerotiorum. Fungal mycelium was amplified with no DNA purification steps (data not shown). Because the direct use of crude samples in the reaction was possible, a standard curve was developed for a mycelium suspension to enable quantitative analysis of fungal samples directly with the qLAMP reaction. The curve showed $75.3 \%$ confidence in fit to data (Fig. 2A). Because the standard and limit detection curves were similar when mycelium was used, only one is presented. The 10-ng sample was the lowest mycelium level detected in duplicate. Even though many samples with even lower levels of mycelium were detected, they were not considered because they were not observed in both duplicate samples. Consequently, $10 \mathrm{ng}$ of mycelium per reaction was considered as the detection limit for $S$. sclerotiorum in samples with no DNA purification steps.

A DNA standard curve was set up for quantitative analysis using Ss-qLAMP up to a dilution point of $0.01 \mathrm{ng}$, with $96.6 \%$ confidence (Fig. 2B). DNA quantities lower than $10 \mathrm{pg}$ (quantification using NanoVue Plus, GE Healthcare, U.K.) showed amplification, although not for both duplicate reactions.

Using $2.5 \mu \mathrm{l}$ (into 200 and $170 \mu \mathrm{l}$ of reaction mixture, split into 50 reactions of $4 \mu \mathrm{l}$ and 170 reactions of $1 \mu \mathrm{l}$ each, respectively) and $1.0 \mu \mathrm{l}$ (added into $100 \mu \mathrm{l}$ of reaction mixture, split into $100 \mathrm{re}-$ actions of $1 \mu \mathrm{l}$ each) of a DNA solution (estimated at $20 \mathrm{ng} / \mu \mathrm{l}$ with a NanoVue Plus), 50, 78, and 58 positive amplifications, respectively, were detected (Table 3). Using the quantification method suggested by Lee et al. (2010) (i.e., the QUIZ method), in which negative amplification values are used as the reference, the initial DNA sample used (estimated at $20 \mathrm{ng} / \mu \mathrm{l}$ ) contained around 40 to 70 copies of DNA per microliter with $95 \%$ reliability. This result suggested that the limit of detection was close to a single copy, 
because decreasing the initial sample DNA quantity per reaction did not impede amplification.

Direct visual analysis of Ss-cLAMP. To test if the LAMP application could provide a rapid and direct identification and allow visual analysis of the results, a protocol was optimized to allow detection by means of the calcein-ion indicator, referred to here as Ss-cLAMP.

In the dNTP concentration test, concentrations of $0.6 \mathrm{mM}$ or lower did not show amplification. A $1.4 \mathrm{mM}$ dNTP concentration showed no difference between the positive and negative control samples. Consequently, a 1.2 mM dNTP concentration was selected for further testing, because it provided good differentiation of positive and negative controls using the naked eye and UV light (data not shown).

Ss-cLAMP sensitivity and specificity. Several concentrations of $S$. sclerotiorum DNA were tested in the Ss-cLAMP reaction, and the detection limit for amplification of both duplicate samples was $10 \mathrm{pg}$ according to all methods used for the analysis (Fig. 3). This 10-pg limit of detection was the same as observed in real-time SsqLAMP reactions. For one of the samples containing $1 \mathrm{fg}$ of DNA, amplification was observed with the Ss-cLAMP reaction; however, because the duplicate of this sample showed a negative result it was disregarded.

No amplification was observed when testing the DNA of other plant pathogens with the Ss-cLAMP protocol (Fig. 3D to F). Importantly, all results were equivalent independent of the analysis method (i.e., agarose gel, UV light, and naked eye) (Fig. 3).

Specific detection and quantification of $S$. sclerotiorum in soil samples with Ss-qLAMP. S. sclerotiorum were specifically detected up to the fourth serial dilution $(20 \mathrm{ng})$ of a mycelium suspension (Fig. 4A). Using these amplification curves, a standard curve was obtained with a 0.91 coefficient of determination (Fig. 4B).
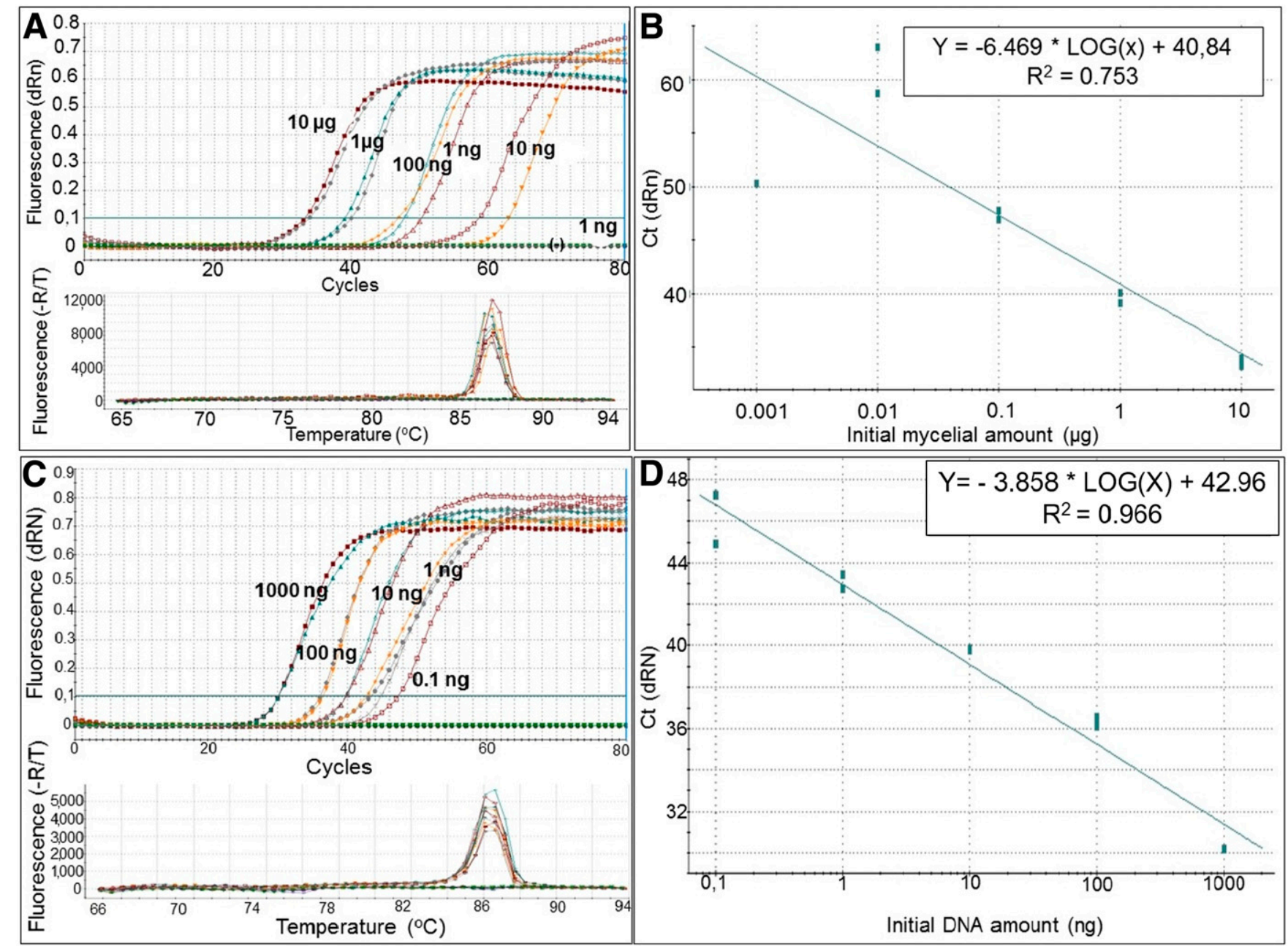

Fig. 2. Sensitivity test and standard curve development for Sclerotinia sclerotiorum ( $A$ and $B$ ) mycelium suspension and (C and D) DNA samples (10 times serial dilutions from 10 $\mu \mathrm{g}$ to $100 \mathrm{fg}$ with mycelium and $1 \mu \mathrm{g}$ to $10 \mathrm{pg}$ with DNA) using Ss-qLAMP. A, Amplification (top) and dissociation (bottom) curves (all reactions performed in duplicate). B, Standard curve generated using the $\mathrm{Ct}$ value $(\mathrm{Ct}=0.1 \mathrm{dRN}$ ) from the serial dilution (from $10 \mu \mathrm{g}$ to $1 \mathrm{ng}$ ) of $\mathrm{S}$. Sclerotiorum mycelium suspension. C, Amplification (top) and dissociation (bottom) curves (all reactions performed in duplicate). D, Standard curve generated using the $\mathrm{Ct}$ value $(\mathrm{Ct}=0.1 \mathrm{dRN})$ from the serial dilution (from $100 \mathrm{ng}$ to $10 \mathrm{pg})$ of $\mathrm{S}$. sclerotiorum DNA samples.

Table 3. Ss-qLAMP reaction results with Sclerotinia sclerotiorum DNA from the standard isolate I-45 (CMM-2030)

\begin{tabular}{|c|c|c|c|c|c|}
\hline $\begin{array}{l}\text { Initial DNA } \\
\text { sample quantity }(\mu \mathrm{l})^{\mathrm{a}}\end{array}$ & $\begin{array}{c}\text { Total reaction } \\
\text { volume }(\mu \mathrm{l})\end{array}$ & $\begin{array}{l}\text { Number of } \\
\text { reactions }\end{array}$ & $\begin{array}{c}\text { Individual reaction } \\
\text { volume }(\mu \mathrm{l})\end{array}$ & $\begin{array}{c}\text { Positive } \\
\text { amplifications }\end{array}$ & $\begin{array}{c}\text { Negative } \\
\text { amplifications }\end{array}$ \\
\hline 2.5 & 200 & 50 & 4 & 50 & 0 \\
\hline 2.5 & 200 & 170 & 1 & 78 & 92 \\
\hline 1.0 & 100 & 100 & 1 & 58 & 42 \\
\hline
\end{tabular}

a $20 \mathrm{ng} / \mu \mathrm{l}$ according to NanoVue Plus (GE Healthcare, U.K.) quantification of S. sclerotiorum DNA from the standard isolate I-45 (CMM-2030). 
All five DNA extraction methods tested allowed for $S$. sclerotiorum DNA recovery from soil samples in at least one of the three dilutions, and by using the standard curves obtained, the quantity of mycelium in each reaction was estimated. The $10^{\circ}$ dilutions were positive for the SDS+PVPP, CTAB, and PowerSoil methods, with mycelium quantities per reaction (or per microliter of eluted DNA) of 10 to $100 \mathrm{ng}$, $>10 \mathrm{ng}$, and 1 to $10 \mu \mathrm{g}$, respectively. The $10^{-1}$ dilutions were positive for all methods evaluated with $>10 \mathrm{ng},>10 \mathrm{ng}, 100 \mathrm{ng}$ to $1 \mu \mathrm{g}, 1$ to $10 \mu \mathrm{g}$, and 1 to $10 \mu \mathrm{g}$ of mycelium per reaction for the SDS,
SDS+PVPP, CTAB+PVPP, CTAB, and PowerSoil methods, respectively. Finally, the $10^{-2}$ dilutions were positive for the CTAB, CTAB+PVPP, and PowerSoil methods, with estimated mycelium quantities of 10 to $100 \mathrm{ng}, 1$ to $10 \mu \mathrm{g}$, and $>10 \mathrm{ng}$ per reaction, respectively.

Using cLAMP for specific identification/detection of $S$. sclerotiorum in plant tissue by direct visual analysis. The PCR reaction detected the presence of $S$. sclerotiorum only in the three samples processed with a DNA extraction step, whereas only one of those processed without a DNA extraction step was positive (Fig. 5A
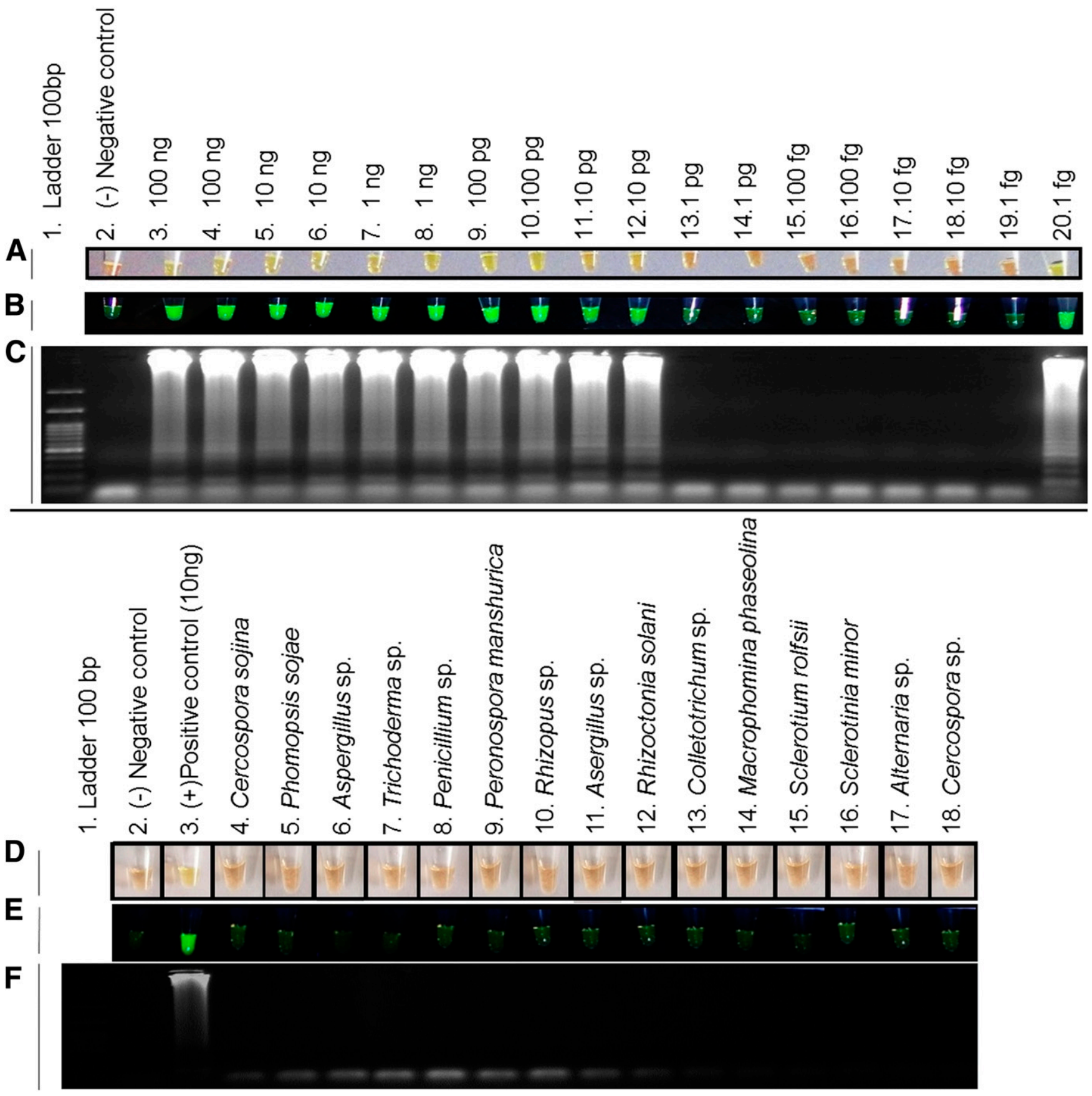

Fig. 3. Amplification of different concentrations of Sclerotinia sclerotiorum DNA (I-45 isolate [CMM-2030]) with the Ss-CLAMP reaction (A to C) and Ss-cLAMP protocol specificity test for $S$. sclerotiorum fungus (D to F). A, Direct visual analysis of the results: red/pink = positive, and green = negative. B, Visualization of tubes in UV light: bright green = positive, and matte green = negative. $\mathbf{C}$, Visualization on a 1\% agarose gel with UV light. Lane: $1=100$ bp DNA molecular weight marker (ladder); $2=$ negative control (no DNA); 3 to $20=$ positive controls with different DNA concentrations of the standard S. sclerotiorum isolate I-45 (CMM-2030), specifically, lanes 3 and $4=100 \mathrm{ng}$; lanes 5 and $6=10 \mathrm{ng}$; lanes 7 and $8=1 \mathrm{ng}$; lanes 9 and $10=100 \mathrm{pg}$; lanes 11 and $12=10 \mathrm{pg}$; lanes 13 and $14=1 \mathrm{pg}$; lanes 15 and $16=100 \mathrm{fg}$; lanes 17 and $18=10 \mathrm{fg}$; and lanes 19 and $20=1 \mathrm{fg}$. D, Direct visual analysis of the results: red/pink = positive, and green = negative. E, Visualization of tubes in UV light: bright green = positive, and matte green = negative. F, Visualization on a $1 \%$ agarose gel with UV light. Lane: $1=100$-bp DNA molecular weight marker (ladder); $2=$ negative control (no DNA); $3=$ positive control (10 ng of S. sclerotiorum standard isolate I-45 [CMM-2030]); $4=$ Cercospora sojina; $5=$ Phomopsis sojae; $6=$ Aspergillus sp.; $7=$ Trichoderma sp.; $8=$ Penicillium sp.; $9=$ Peronospora manshurica; $10=$ Rhizopus sp.; $11=$ Aspergillus sp.; 12 = Rhizoctonia solani; 13 = Colletotrichum sp.; 14 = Macrophomina phaseolina; $15=$ Sclerotium rolfsii; $16=$ S. minor, $17=$ Alternaria sp.; and $18=$ Cercospora $\mathrm{sp}$. 
and B). When the Ss-cLAMP reaction was used, S. sclerotiorum was specifically detected on diseased plant tissue with (data not shown) and without the DNA extraction step in all three samples analyzed (Fig. 5C and D). The Ss-cLAMP detection process took around 1 $\mathrm{h}$, and the result was determined by direct visual detection (Fig. 5D).

\section{Discussion}

LAMP reactions are very specific and can include specificity up to the level of formae specialis, pathovar, and race (Ghosh et al. 2015; Kubota et al. 2011; Peng et al. 2014). However, in a species-specific test, a partial detection of the species that detects only some populations is not desirable, nor is the detection of other species (Bustin et al. 2009; ISTA 2007). Thus, the Ss-LAMP primer set was efficient and specific (Tables 1 and 3; Figs. 3, 4, and 5; Supplementary Fig. S3) for detecting $S$. sclerotiorum.
Many reaction reagent concentrations were analyzed to optimize our custom reaction mixture. Reagent concentrations were determined based on many factors related to the efficiency, quality, sensitivity, and specificity of amplification. A $0.5 \mathrm{X}$ EvaGreen concentration, 0.8:0.4:0.2 $\mu \mathrm{M}$ primer concentrations, and a $0.4 \mathrm{mM}$ dNTP concentration were selected as the best conditions and are comparable to other LAMP assays (Cheng et al. 2016; Lee et al. 2009; Nagamine et al. 2002; Notomi et al. 2000; Tomlinson et al. 2007).

During an initial assay to test reaction specificity, DNA of several other plant pathogens was not amplified; however, the DNA of $S$. $m i$ nor and Aspergillus sp. was amplified (Supplementary Fig. S3A). The DNA quality of all these samples was high enough for successful amplification reactions with ITS primers (Table 1). Consequently, further optimization was required. Betaine and magnesium chloride reagents influence reaction specificity, because betaine facilitates
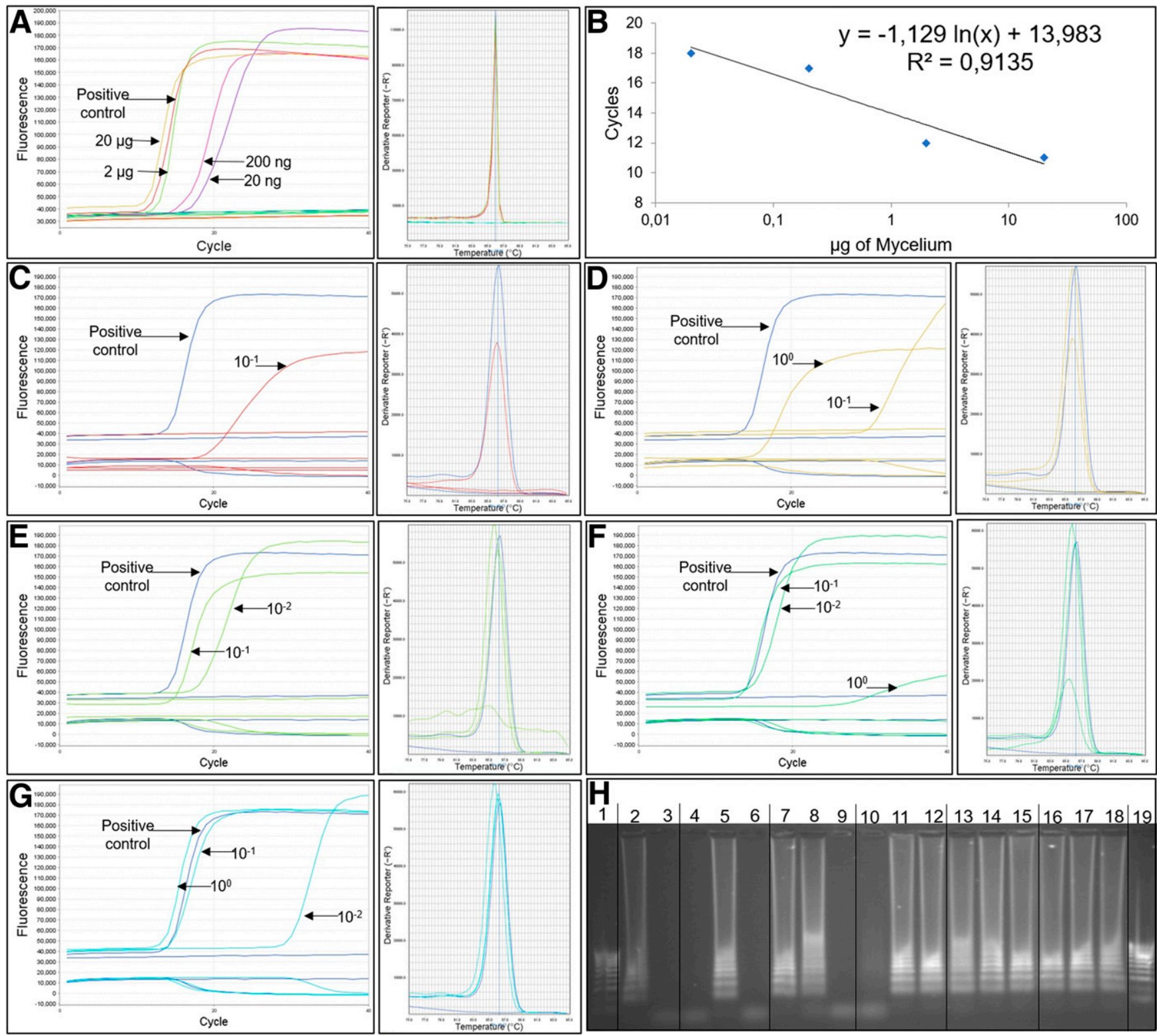

Fig. 4. Specific Sclerotinia sclerotiorum amplification using the Ss-qLAMP reaction to detect and quantify a mycelium suspension and artificially inoculated soil samples. A Amplification (left) and melting (right) curves of S. sclerotiorum mycelium suspension 10-fold serially diluted from $20 \mu \mathrm{g}$ to $200 \mathrm{fg}$, and B, its standard curve (Ct $=50,000)$. C to $G$ show amplification (left) and melting (right) curves for samples obtained using five different DNA extraction methods (C, SDS method; D, SDS+PVPP method; $E$, CTAB+PVPP method; F, CTAB method; and G, PowerSoil method) to acquire S. sclerotiorum DNA from artificially inoculated soil samples, in three 10-fold serial dilutions $\left(10^{0}, 10^{-1}\right.$, and $\left.10^{-2}\right)$ of the final DNA obtained. $\mathbf{H}$, Agarose gel $(1 \%)$ with the products of the Ss-qLAMP reactions with soil samples. Lanes: 1 and $19=100$-bp ladder; $2=$ positive control (10 ng of S. sclerotiorum I-45 [CMM-2030] isolate); $3=$ negative control (no DNA); $4=$ SDS method with $10^{0}$ dilution (undiluted); $5=$ SDS method with $10^{-1}$ dilution; $6=$ SDS method with $10^{-2}$ dilution; $7=$ SDS +PVPP method with $10^{0}$ dilution; $8=$ SDS+PVPP method with $10^{-1}$ dilution; $9=$ SDS + PVPP method with $10^{-2}$ dilution; $10=\mathrm{CTAB}+\mathrm{PVPP}$ method with $10^{0}$ dilution; $11=\mathrm{CTAB}+\mathrm{PVPP}$ method with $10^{-1}$ dilution; $12=\mathrm{CTAB}+\mathrm{PVPP}$ method with $10^{-2}$ dilution; $13=\mathrm{CTAB}$ method with $10^{0}$ dilution; $14=\mathrm{CTAB}$ method with $10^{-1}$ dilution; $15=\mathrm{CTAB}$ method with $10^{-2}$ dilution; $16=$ PowerSoil method with $10^{0}$ dilution; $17=$ PowerSoil method with $10^{-1}$ dilution; and 18 = PowerSoil method with $10^{-2}$ dilution. 
DNA strand separation, reducing nonspecific annealing of primers (Frackman et al. 1998; Henke et al. 1997), and magnesium chloride stabilizes the double strand formed by nonspecific primer annealing when in excessive concentrations. In the present study, these two reagents were crucial for LAMP reaction specificity, corroborating the study of Liu et al. (2013). The use of $1 \mathrm{M}$ betaine, no extra magnesium chloride, and a reaction time of 40 min (Supplementary Fig. S2) kept the reaction specific to $S$. sclerotiorum. These conditions were selected as standard for subsequent reactions.

After optimizing Ss-qLAMP reaction steps, all non-S. sclerotiorum DNA, which included 36 plant pathogens and eight plant DNA (including those that were nonspecifically amplified earlier), failed to amplify (Table 1; Supplementary Fig. S3B to D). The assay was thus specific to $S$. sclerotiorum, which requires a specific detection test, as mentioned by several authors (Bustin et al. 2009; ISTA 2007; Jaccoud Filho and Reeves 1993; Sheppard 2002). Due to the specificity of the Ss-qLAMP protocol, it holds promise as a means of detecting $S$. sclerotiorum in several sample types including soil, airborne spores, seeds, and plant materials, as well as for the rapid identification of the pathogen when necessary.

Many important DNA hosts were analyzed with the Ss-qLAMP reaction, including soybean, OSR, bean, and potato, and no amplification was detected (Fig. 4). Because genomic DNA from many plant hosts, such as lettuce, sunflower, carrot, and cotton, shows no DNA similarity with the primer set sequences, the Ss-LAMP protocol may prove useful for detection in plant material from many other S. sclerotiorum hosts.

As other authors have reported (Iwamoto et al. 2003; Lee et al. 2009), crude samples could be used directly in the Ss-LAMP reaction, allowing development of a standard curve with a mycelium suspension to quantitatively analyze fungal sample directly in the qLAMP reaction. This resulted in a $75.3 \%$ data adjustment (Fig.
2A), and $10 \mathrm{ng}$ of mycelium per reaction was considered the detection limit for $S$. sclerotiorum in samples with no DNA purification steps.

Using the quantification method suggested by Lee et al. (2010), the Ss-LAMP detection limit was close to a single DNA copy. The single-copy amplification detection limit was previously observed, including in PCR reactions, and is the basis of modern technologies for DNA sample quantification, such as digital PCR. These reactions are similar to qPCR, but the reaction volume is divided into hundreds or thousands of small reactions that simultaneously react with negative and positive controls, which are used as references to accurately count the target molecules (Baker 2012). The same principle forms the basis of the QUIZ method (Lee et al. 2010) that was used in the present study (Table 3). As in our study, other authors have highlighted the ability of LAMP to detect the presence of only one copy of target DNA (Nkouawa et al. 2009; Xu et al. 2013).

A DNA standard curve was set up for quantitative analysis using Ss-qLAMP up to a dilution point of $0.01 \mathrm{ng}$, with data adjustment of 96.6\% (Fig. 2B). Quantification accuracy declined when the concentration of target molecules decreased to less than $10 \mathrm{pg}$. Because amplification can start quickly or it can take time, and depending on the linearity expected in the proposed curve, low target concentrations can yield similar amplification quantities to higher concentrations of samples. To ensure more accurate results in Ss-qLAMP assays, and to avoid overestimation or underestimation, it is strongly recommended that duplicates are used, as is also recommended in the qPCR minimum information manual for assays (Bustin et al. 2009). This recommendation also applies to Ss-cLAMP assays, especially with low levels of DNA samples (as observed in Fig. 3A to C).

Artificially inoculated soil samples were used to test the SsqLAMP reaction. Soil is a primary source of pathogens in the field, and its phytosanitary quality is crucial to farmers (Ophel-Keller et al.

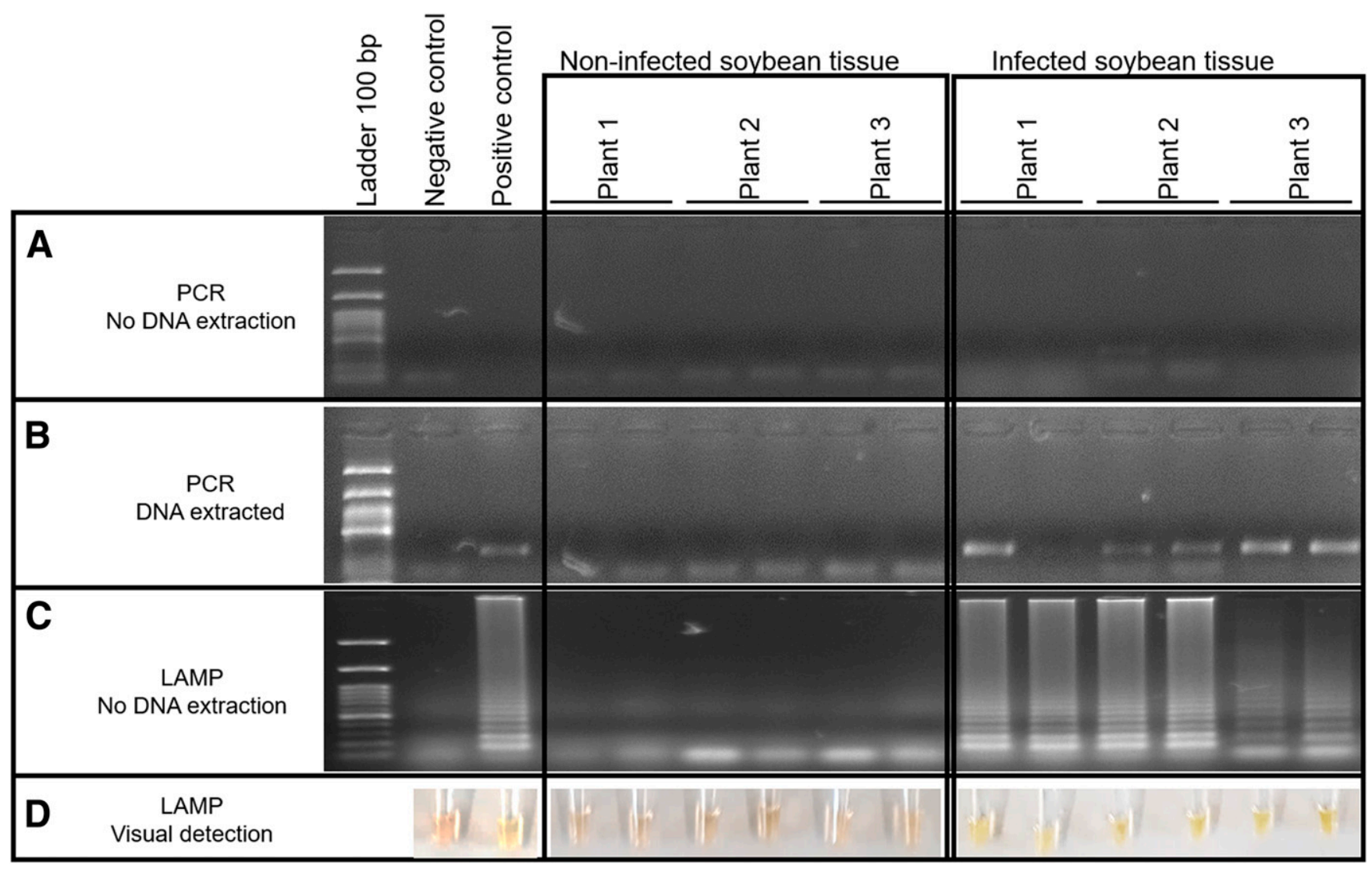

Fig. 5. Specific amplification of Sclerotinia sclerotiorum from three noninfected and three infected plant tissues. A, Amplification of a 252-bp fragment with the SsF/SsR primer pair in a standard PCR reaction that directly used plant tissue samples without a DNA extraction process, visualized in $1 \%$ agarose gels. B, Amplification of a 252 -bp fragment with the SsF/SsR primer pair in a standard PCR reaction using DNA that was extracted from plant samples, visualized in $1 \%$ agarose gels. C, Amplification of S. sclerotiorum with the SsLAMP primer set in a cLAMP reaction using plant samples directly without a DNA extraction step, visualized in $1 \%$ agarose gels. D, Visual detection of the specific $S$. sclerotiorum amplification with the Ss-LAMP primer set in a cLAMP reaction using plant samples directly without a DNA extraction step; pink = no amplification, and green = amplification 
2008). Besides pathogens, soil is host to myriad other microorganisms and potential enzymatic inhibitors and DNA-binding compounds, such as humic acids and phenolic compounds (Albers et al. 2013; Opel et al. 2010; Wilson 1997). Analyzing soil samples with nucleic acid amplification techniques is a challenge (OphelKeller et al. 2008).

Five different methods of DNA extraction were used to isolate target $S$. sclerotiorum from artificially inoculated soil samples that were prepared in a series of three 10 -fold dilutions. The $S$. sclerotiorum mycelia was detected and quantitatively estimated using all five extraction methods with real-time and quantitative Ss-LAMP reactions in at least one of the three eluted DNA dilutions used (Fig. 4). The DNA from all the three dilutions used was detected by Ss-qLAMP when using a simple CTAB protocol with all custom reagents or a sophisticated modern commercial kit (i.e., PowerSoil) (Fig. 4F to H).

The extraction methods differed in the amount of DNA recovered, the proportion of contaminants eliminated, their expense, and the time required. Based on amplification from the most contaminated sample $\left(10^{\circ}\right)$, the cleanliness of the DNA was best with the PowerSoil method, and then, in order, with SDS+PVPP, CTAB, and CTAB+PVPP and SDS. Based on the most diluted sample $\left(10^{-2}\right)$, the best methods for recovering higher levels of DNA were CTAB, CTAB+PVPP, and PowerSoil. In terms of price and time, PowerSoil was relatively expensive, although along with the SDS methods it was the least time consuming at around $30 \mathrm{~min}$, whereas the CTAB methods took about $90 \mathrm{~min}$.

Because all of its reagents are well known, an advantage of the CTAB method is its potential for use with larger sample volumes, such as, for example, in 15- or 50-ml volumes in centrifuge tubes. This characteristic could contribute to the problem of sampling (because it allows increasing the sample size), widely known in these types of soil analyses (Ophel-Keller et al. 2008).

Depending on available facilities and with knowledge of the differences among these extraction methods (advantages and disadvantages), anyone could apply the Ss-LAMP reaction for detecting and quantifying $S$. sclerotiorum in soil samples, as was done here (Fig. 4).

Many types of samples (air, seeds, petals, and other plant tissue) have been tested using nucleic acid amplification techniques (almost all by PCR and real-time PCR) to detect S. sclerotiorum (AbdElmagid et al. 2013; Botelho et al. 2015; Duan et al. 2014a; Freeman et al. 2002; Grabicoski et al. 2015; Jones et al. 2015; Parker et al. 2014; Qin et al. 2011; Rogers et al. 2009; Yin et al. 2009; Ziesman et al. 2016). So far though, few or no reports detect $S$. sclerotiorum from soil samples or by means of LAMP.

For the Ss-cLAMP assay we developed based on calcein ion-metal indication, the detection limit was $10 \mathrm{pg}$ (Fig. 3A). This limit of detection was the same as observed for the real-time Ss-qLAMP reactions. No amplification was observed when testing the DNA of other plant pathogens (Fig. 3D to F). Thus, Ss-cLAMP can provide rapid diagnosis of $S$. sclerotiorum. Ss-cLAMP only requires a $40 \mathrm{~min}$ reaction-incubation time, and the results are directly analyzed through visual cues observable with the naked eye or with UV light.

Using naturally infected soybean plants, Ss-cLAMP provided a rapid and reliable method for detecting the important soil-, air-, and seed-borne plant pathogen $S$. sclerotiorum in infected tissues (Fig. 5). Direct analysis of the plant tissue was possible (i.e., no DNA extraction was required) (Fig. 5C), and the detection process only took a total of about $1 \mathrm{~h}$, including sample collection ( $5 \mathrm{~min}$ ), preparation (15 $\mathrm{min}$ ), incubation of the reaction ( $40 \mathrm{~min}$ ), and analysis of the results through direct visualization with the naked eye (Fig. 5D). Compared with PCR, LAMP was more sensitive to detection because there was lower interference from inhibitors, given that DNA extraction was not required, and because PCR requires the DNA extraction step to detect the pathogen in all samples (Fig. 5A to C).

The cLAMP reaction worked for specific detection of S. sclerotiorum. Compared with other amplification methods, such as PCR, no sophisticated equipment is required, nor do the reaction tubes require manipulation and opening at the end of the incubation period to analyze the results. This technique only requires a $65^{\circ} \mathrm{C}$ heating block and direct visualization of the tubes. There are other ion-metal indicators that could offer similarly promising results, including hydroxynaphthol blue (Duan et al. 2014a; Ghosh et al. 2015; Goto et al. 2009) and copper sulfate (Zoheir and Allam 2011).

There are reports of several tests for specific amplification of $S$. sclerotiorum, primarily using real-time or conventional PCR (AbdElmagid et al. 2013; Botelho et al. 2015; Freeman et al. 2002; Grabicoski et al. 2015; Parker et al. 2014; Qin et al. 2011; Rogers et al. 2009; Yin et al. 2009). Despite the numerous qualities of PCR reactions, they still require a thermal cycler with precise temperature ramping, they take around $2 \mathrm{~h}$ for each reaction, and they are greatly influenced by inhibitors, mainly organic compounds present in plant samples that reduce the detection limit of DNA in samples and require DNA purification steps prior to amplification reactions (Fig. 5) (Abu Al-Soud and Rådström 1998, 2000; Grabicoski et al. 2015; Moreira 1998; Wilson 1997).

Duan et al. (2014a) developed a test based on LAMP amplification for $S$. sclerotiorum using primers for hypothetical protein $\mathrm{SS}_{\mathrm{G}}$ 14143 and detection using the metal ion indicator hydroxynaphthol blue. To the best of our knowledge, there is no report using LAMP to detect $S$. sclerotiorum with real-time analysis or using calcein as the detection indicator. In addition, the more options available for detecting $S$. sclerotiorum with different target DNA sequences, the greater the chances for accurate results.

The LAMP reactions described here, both Ss-qLAMP and SscLAMP, are applicable using simple equipment (a heating block), because only one temperature is required for all the amplifications $\left(65^{\circ} \mathrm{C}\right)$. The reaction is thus portable and field deployable, as demonstrated by Kubota et al. $(2011,2013)$, who performed detection tests using a modified tea mug. In order to improve the portability of detection methods, equipment was developed that supports the detection of real-time results, including LAMP reactions (as well as qLAMP), using heating blocks coupled to a detection system for both fluorescent and turbidity dyes. An example of this equipment is $\mathrm{Ge}-$ nie II (OptiGene), which was used in the present study.

Because the reagents used in LAMP procedures have greater stability at room temperature, and because the technique uses portable heating equipment, tests can be made directly in the field in about 1 $\mathrm{h}$, as demonstrated in studies using LAMP to detect Phytophthora ramorum (Tomlinson et al. 2007) and Botrytis cinerea (Duan et al. 2014b).

This study presents a LAMP procedure that is rapid, specific, and requires no DNA extraction from samples before use. The Ss-LAMP test allows direct application with the possibility of quantitation of results with high sensitivity and specificity for detecting $S$. sclerotiorum. The protocols can be applied for various purposes, such as the analysis of plant tissue samples (leaves, stems, pods, petals, and seeds), detecting spore presence in airborne monitoring systems, soil samples, and the rapid identification of this fungus. The level of $S$. sclerotiorum in samples from different crops, including those of great economic importance, such as soybean and canola, is easily quantified. Thus, the reactions presented here should assist in the rapid and correct diagnosis of $S$. sclerotiorum, thereby contributing to improved management and pathogen control strategies that will reduce the extent of disease caused by this plant pathogen.

In summary, LAMP-based protocols for the specific detection of $S$. sclerotiorum were developed. One protocol provides real-time and quantitative analysis (Ss-qLAMP) and another direct visual analysis of results (Ss-cLAMP). The diagnostic results of these protocols were obtained in less than $1 \mathrm{~h}$, allowing for rapid and accurate diagnosis of $S$. sclerotiorum in many kinds of contaminated samples (i.e., directly from fungal, plant tissue, and soil samples).

\section{Acknowledgments}

We are grateful to National Institute of Agricultural Botany (NIAB) for their support, especially to Helen Appleyard by the availability of DNA from plants and microorganisms. We are grateful to the professors Fernando C. Juliatti, João Vida, and Ailton Reis for providing the I-45, I-47, and I-56 isolates, respectively.

\section{Literature Cited}

Abd-Elmagid, A., Garrido, P. A., Hunger, R., Lyles, J. L., Mansfield, M. A., Gugino, B. K., Smith, D. L., Melouk, H. A., and Garzon, C. D. 2013. 
Discriminatory simplex and multiplex PCR for four species of the genus Sclerotinia. J. Microbiol. Methods 92:293-300.

Abu Al-Soud, W., and Rådström, P. 1998. Capacity of nine thermostable DNA polymerases to mediate DNA amplification in the presence of PCR-inhibiting samples. Appl. Environ. Microbiol. 64:3748-3753.

Abu Al-Soud, W., and Rådström, P. 2000. Effects of amplification facilitators on diagnostic PCR in the presence of blood, feces, and meat. J. Clin. Microbiol. 38: 4463-4470.

Albers, C. N., Jensen, A., Baelum, J., and Jacobsen, C. S. 2013. Inhibition of DNA polymerases used in Q-PCR by structurally different soil-derived humic substances. Geomicrobiol. J. 30:675-681.

Baker, M. 2012. Digital PCR hits its stride. Nat. Methods 9:541-544.

Boland, G. J., and Hall, R. 1994. Index of plant hosts to Sclerotinia sclerotiorum. Can. J. Plant Pathol. 16:93-108.

Bolton, M. D., Thomma, B. P. H. J., and Nelson, B. D. 2006. Sclerotinia sclerotiorum (Lib.) de Bary: Biology and molecular traits of a cosmopolitan pathogen. Mol. Plant Pathol. 7:1-16.

Botelho, L. S., Barrocas, E. M., Machado, J. C., and Martins, R. S. 2015. Detection of Sclerotinia sclerotiorum in soybean seeds by conventional and quantitative PCR techniques. J. Seed Sci. 37:55-62.

Bustin, S. A., Benes, V., Garson, J. A., Hellemans, J., Huggett, J., Kubista, M., Mueller, R., Nolan, T., Pfaffl, M. W., Shipley, G. L., Vandesompele, J., and Wittwer, C. T. 2009. The MIQE guidelines: Minimum information for publication of quantitative real-time PCR experiments. Clin. Chem. 55: 611-622.

Cheng, N., Xu, Y., Yan, X., Shang, Y., Zhu, P., Tian, W., Liang, Z., and Xu, W. 2016. An advanced visual qualitative and EVA Green-based quantitative isothermal amplification method to detect Listeria monocytogenes. J. Food Saf. 36:237-246.

del Río, L. E., Bradley, C. A., Henson, R. A., Endres, G. J., Hanson, B. K., McKay, K., Halvorson, M., Porter, P. M., Le Gare, D. G., and Lamey, H. A. 2007. Impact of Sclerotinia stem rot on yield of canola. Plant Dis. 91:191-194.

Denschlag, C., Rieder, J., Vogel, R. F., and Niessen, L. 2014. Real-time loopmediated isothermal amplification (LAMP) assay for group specific detection of important trichothecene producing Fusarium species in wheat. Int. J. Food Microbiol. 177:117-127.

Duan, Y., Ge, C., Zhang, X., Wang, J., and Zhou, M. 2014a. A rapid detection method for the plant pathogen Sclerotinia sclerotiorum based on loop-mediated isothermal amplification (LAMP). Australas. Plant Pathol. 43: 61-66.

Duan, Y., Ge, C., Zhang, X., Wang, J., and Zhou, M. 2014b. Development and evaluation of a novel and rapid detection assay for Botrytis cinerea based on loop-mediated isothermal amplification. PLoS One 9:e111094.

Ferreira, M. E., and Grattapaglia, D. 1998. Introdução ao uso de marcadores RAPD e RFLP em análise genética. $3^{\mathrm{a}}$ ed. [Introduction to the Use of RAPD and RFLP Markers in Genetic Analysis.] EMBRAPA - Cenargen, Brasília-DF, Brazil. (In Portuguese.)

Frackman, B. S., Kobs, G., Simpson, D., and Storts, D. 1998. Betaine and DMSO: Enhancing agents for PCR. Promega Notes 65:9-12.

Freeman, J., Ward, E., Calderon, C., and McCartney, A. 2002. A polymerase chain reaction (PCR) assay for the detection of inoculum of Sclerotinia sclerotiorum. Eur. J. Plant Pathol. 108:877-886.

Ghosh, R., Nagavardhini, A., Sengupta, A., and Sharma, M. 2015. Development of loop-mediated isothermal amplification (LAMP) assay for rapid detection of Fusarium oxysporum f. sp. ciceris - wilt pathogen of chickpea. BMC Res. Notes 8:40.

Goto, M., Honda, E., Ogura, A., Nomoto, A., and Hanaki, K. 2009. Colorimetric detection of loop-mediated isothermal amplification reaction by using hydroxy naphthol blue. Biotechniques 46:167-172.

Grabicoski, E. M. G., Jaccoud-Filho, D. S., Pileggi, M., Henneberg, L., Pierre, M. L. C., Vrisman, C. M., and Dabul, A. N. G. 2015. Rapid PCR-based assay for Sclerotinia sclerotiorum detection on soybean seeds. Sci. Agric. 72: 69-74

Heid, C. A., Stevens, J., Livak, K. J., and Williams, P. M. 1996. Real time quantitative PCR. Genome Res. 6:986-994.

Henke, W., Herdel, K., Jung, K., Schnorr, D., and Loening, A. S. 1997. Betaine improves the PCR amplification of GC-rich DNA sequences. Nucleic Acids Res. 25:3957-3958.

Innis, M. A., Gelfand, D. H., Sninsky, J. J., and White, T. J. 1990. PCR Protocols: A Guide to Methods and Applications. 1. Academic Press, San Diego, CA.

International Seed Testing Association (ISTA). 2007. ISTA Method Validation for Seed Testing. ISTA, Bassersdorf, Switzerland.

Iwamoto, T., Sonobe, T., and Hayashi, K. 2003. Loop-mediated isothermal amplification for direct detection of Mycobacterium tuberculosis complex, $M$. avium and $M$. intracellulare in sputum samples. J. Clin. Microbiol. 41: 2616-2622.

Jaccoud-Filho, D. S., and Reeves, J. C. 1993. Detection and identification of Phomopsis species in soya bean seeds using PCR. Proceedings of 1st ISTA Plant Disease Committee. Symposium on Seed Health Testing, pp. 34-43. ISTA, Sherwood Park, AB, Canada.

Jones, S. J., Pilkington, S. J., Gent, D. H., Hay, F. S., and Pethybridge, S. J. 2015. A polymerase chain reaction assay for ascosporic inoculum of Sclerotinia species. N. Z. J. Crop Hortic. Sci. 43:233-240.
Kubota, R., Labarre, P., Singleton, J., Beddoe, A., Weigl, B. H., Alvarez, A. M. and Jenkins, D. M. 2011. Non-instrumented nucleic acid amplification (NINA) for rapid detection of Ralstonia solanacearum race 3 biovar 2. Biol. Eng. Trans. 4:69-80.

Kubota, R., Labarre, P., Weigl, B. H., Li, Y., Haydock, P., and Jenkins, D. M. 2013. Molecular diagnostics in a teacup: Non-instrumented nucleic acid amplification (NINA) for rapid, low cost detection of Salmonella enterica. Chin. Sci. Bull. 58:1162-1168.

Lee, D., La Mura, M., Allnutt, T., Powell, W., and Greenland, A. 2009. Isothermal amplification of genetically modified DNA sequences directly from plan tissues lowers the barriers to high-throughput and field-based genotyping. J. Agric. Food Chem. 57:9400-9402.

Lee, D., La Mura, M., Greenland, A., and Mackay, I. 2010. Quantitation using informative zeros (QUIZ): Application for GMO detection and quantification without recourse to certified reference material. Food Chem. 118:974-978.

Liu, J., Xu, L., Guo, J., Chen, R., Grisham, M. P., and Que, Y. 2013. Development of loop-mediated isothermal amplification for detection of Leifsonia xyli subsp. xyli in sugarcane. BioMed Res. Int. 2013:357692.

Moreira, D. 1998. Efficient removal of PCR inhibitors using agarose-embedded DNA preparations. Nucleic Acids Res. 26:3309-3310.

Mori, Y., Kitao, M., Tomita, N., and Notomi, T. 2004. Real-time turbidimetry of LAMP reaction for quantifying template DNA. J. Biochem. Biophys. Methods 59:145-157.

Nagamine, K., Hase, T., and Notomi, T. 2002. Accelerated reaction by loopmediated isothermal amplification using loop primers. Mol. Cell. Probes 16: 223-229.

Neergaard, P. 1979. Seed Pathology, 1st Ed. MacMillan Press, London U.K.

Neonakis, I. K., Spandidos, D. A., and Petinaki, E. 2011. Use of loop-mediated isothermal amplification of DNA for the rapid detection of Mycobacterium tuberculosis in clinical specimens. Eur. J. Clin. Microbiol. Infect. Dis. 30: 937-942.

Nkouawa, A., Sako, Y., Nakao, M., Nakaya, K., and Ito, A. 2009. Loop-mediated isothermal amplification method for differentiation and rapid detection of Taenia species. J. Clin. Microbiol. 47:168-174.

Notomi, T., Okayama, H., Masubuchi, H., Yonekawa, T., Watanabe, K., Amino, N., and Hase, T. 2000. Loop-mediated isothermal amplification of DNA. Nucleic Acids Res. 28:e63.

Opel, K. L., Chung, D., and McCord, B. R. 2010. A study of PCR inhibition mechanisms using real time PCR. J. Forensic Sci. 55:25-33.

Ophel-Keller, K., McKay, A., Hartley, D., Herdina, and Curran, J. 2008 Development of a routine DNA-based testing service for soilborne diseases in Australia. Australas. Plant Pathol. 37:243-253.

Parida, M., Posadas, G., Inoue, S., Hasebe, F., and Morita, K. 2004. Real-time reverse transcription loop-mediated isothermal amplification for rapid detection of West Nile virus. J. Clin. Microbiol. 42:257-263.

Parker, M. L., McDonald, M. R., and Boland, G. J. 2014. Evaluation of air sampling and detection methods to quantify airborne ascospores of Sclerotinia sclerotiorum. Plant Dis. 98:32-42.

Peltier, A. J., Bradley, C. A., Chilvers, M. I., Malvick, D. K., Mueller, D. S., Wise, K. A., and Esker, P. D. 2012. Biology, yield loss and control of Sclerotinia stem rot of soybean. J. Integr. Pest Manag. 3:1-7.

Peng, J., Zhang, H., Chen, F., Zhang, X., Xie, Y., Hou, X., Li, G., and Pu, J. 2014 Rapid and quantitative detection of Fusarium oxysporum f. sp. cubense race 4 in soil by real-time fluorescence loop-mediated isothermal amplification. J. Appl. Microbiol. 117:1740-1749.

Purdy, L. H. 1979. Sclerotinia sclerotiorum: History, diseases and symptomatology, host range, geographic distribution, and impact. Phytopathology 69:875880 .

Qin, L., Fu, Y., Xie, J., Cheng, J., Jiang, D., Li, G., and Huang, J. 2011. A nestedPCR method for rapid detection of Sclerotinia sclerotiorum on petals of oilseed rape (Brassica napus). Plant Pathol. 60:271-277.

Rogers, S. L., Atkins, S. D., and West, J. S. 2009. Detection and quantification of airborne inoculum of Sclerotinia sclerotiorum using quantitative PCR. Plant Pathol. 58:324-331.

Sambrook, J., and Russell, D. W. 2001. Molecular Cloning: A Laboratory Manual, 3rd Ed. Cold Spring Harbor Laboratory Press, Cold Spring Harbor, NY.

Sheppard, J. W. 2002. Fitness for purpose: ISTA method validation in seed health testing. Pages 29-46 in: Seed-Borne Fungi: A Contribution to Routine Seed Health Analysis. J. C. Machado, C. J. Langerak, and D. S. Jaccoud-Filho, eds. ISTA, Bassersdorf, Switzerland.

Thai, T. C. T., Mai, Q. L., Cuong, D. V., Parida, M., Minekawa, H., Notomi, T., Hasebe, F., and Morita, K. 2004. Development and evaluation of a novel loop-mediated isothermal amplification method for rapid detection of severe acute respiratory syndrome coronavirus. J. Clin. Microbiol. 42:1956-1961.

Tomita, N., Mori, Y., Kanda, H., and Notomi, T. 2008. Loop-mediated isothermal amplification (LAMP) of gene sequences and simple visual detection of products. Nat. Protoc. 3:877-882.

Tomlinson, J. A., Barker, I., and Boonham, N. 2007. Faster, simpler, more-specific methods for improved molecular detection of Phytophthora ramorum in the field. Appl. Environ. Microbiol. 73:4040-4047.

White, T. J., Bruns, T., Lee, S., and Taylor, J. 1990. Amplification and direct sequencing of fungal ribosomal RNA genes for phylogenetics. Pages 315-322 in: PCR Protocols: A Guide to Methods and Applications. M. A. 
Innis, D. H. Gelfand, J. J. Sninsky, and T. J. White, eds. Academic Press, San Diego, CA.

Wilson, I. G. 1997. Inhibition and facilitation of nucleic acid amplification. Appl. Environ. Microbiol. 63:3741-3751.

Xu, J., Zheng, Q., Yu, L., Liu, R., Zhao, X., Wang, G., Wang, Q., and Cao, J. 2013. Loop-mediated isothermal amplification (LAMP) method for detection of genetically modified maize T25. Food Sci. Nutr. 1:432-438.
Yin, Y., Ding, L., Liu, X., Yang, J., and Ma, Z. 2009. Detection of Sclerotinia sclerotiorum in planta by a real-time PCR assay. J. Phytopathol. 157:465-469.

Ziesman, B. R., Turkington, T. K., Basu, U., and Strelkov, S. E. 2016. A quantitative PCR system for measuring Sclerotinia sclerotiorum in canola (Brassica napus). Plant Dis. 100:984-990.

Zoheir, K. M. A., and Allam, A. A. 2011. A rapid improved method for sexing embryo of water buffalo. Theriogenology 76:83-87. 